DOI: 10.21005/pif.2020.44.B-06

\title{
IN SEARCH OF AN IDEAL PLACE TO LIVE, FROM THE PHILOSOPHY OF FENG SHUI, THROUGH THE VISIONS OF LE CORBUSIER AND UNITÉ D'HABITATION, TO THE NIGHTINGALE MODEL \\ W POSZUKIWANIU IDEALNEGO MIEJSCA DO ŻYCIA, OD FILOZOFII FENG SHUI, PORZEZ WIZJE LE CORBUSIERA I UNITÉ D'HABITATION, NA MODELU NIGHTINGALE SKOŃCZYWSZY
}

\section{Monika Motylska}

mgr inż.

Author's Orcid number: 0000-0002-1182-385X

Doktorantka Instytutu Architektury i Urbanistyki

Politechniki Łódzkiej

\begin{abstract}
The feng shui philosophy, Le Corbusier's visions and the Nightingale model are three seemingly different approaches to the issue of housing. This article is an attempt to find similarities among all of the concepts and to indicate the main contrasts between them. The aim of this article is to find a set of features that make a perfect place to live.
\end{abstract}

Key words: feng shui, interior design, Le Corbusier, living comfort, Nightingale model, Unité d'Habitation.

\section{STRESZCZENIE}

Filozofia feng shui, wizje Le Corbusiera oraz model Nightingale stanowią trzy, na pozór odmienne, ujęcia problematyki mieszkalnictwa. Niniejszy artykuł jest próbą znalezienia podobieństw wśród wszystkich koncepcji oraz wskazania głównych kontrastów pomiędzy nimi. Powyższe ma za zadanie skompletowanie zespołu cech stanowiących o idealnym miejscu do życia.

Słowa kluczowe: aranżacja wnętrza, feng shui, komfort życia, Le Corbusier, model Nightingale, Unité d'Habitation. 


\section{INTRODUCTION}

Wellbeing at home is one of the basic, deeply rooted human needs (Rybczyński W. 1996). The place of living and stay has a huge impact on the quality of human life, on the emotions it feels. The house has various functions - it is an asylum, a place of rest, relaxation, entertainment, sometimes work or study, therefore, it should be even more in the area of human comfort. But what is this comfort and how is it achievable? The first association that comes to mind for many people, in the context of comfort in an apartment, is thermal comfort. The fact is that this is what they teach in schools, it is also the first association of Google search engine, after entering the key-phrase: comfort at home. Ideal temperature is not enough, however, if we neglect other, much more important spheres. So what factors determine the ideal place to live? Is there a universal canon of guidelines?

This article deals with three seemingly completely different theories, but with a common denominator - each of them is a kind of recipe for a perfect place to live, according to the authors. The main aim of the article is to indicate the similarities and contrasts of selected visions through the analysis of issues and their recognition in the context of a selected set of features relating mainly to architecture, interior design, social aspect and the environment.

\section{FENG SHUI PHILOSOPHY}

Since ancient times, China has known the philosophy of feng shui, which boils down to the art of harmonious interaction with the environment. The Chinese believed in a strong correlation between the fate of people and their place on earth. According to the statements there is balance and order in the world and man is able to attract positive energy (ch'i) through appropriate actions. This philosophy used to be not only a way of life but also a kind of death because an action like choosing a burial place had to be in accordance with art. Nowadays feng shui has become a little bit adapted to Western culture and deals mainly with the energy and harmony of nature which is supposed to balance the life forces of a person which have an impact on his or her destiny. The essence of philosophy is logic, this tool allows man to see how the surrounding affects his fate and thus improve the quality of living space at home or at work. A comfortable and healthy energetic atmosphere brings people closer to achieving success in all areas of life (Gęsiarz M. 2009, p. 13-17).

The art of feng shui is a very extensive issue which is evidenced by the fact that during the five thousand years of its development several seemingly contradictory systems appeared: The School of Form, the School of Intuition and the School of Compass. Particularly interesting are the assumptions of the School of Forms which was based primarily on the observation of various forms of landscape and their impact on the environment. It introduced equivalents of terrain in the form of animals and any human intervention in the space had to comply with philosophy to not disturb the balance prevailing in a given area. The recommendations of this system concerned both the location of the house, its shape and interior design. While studying the detailed guidelines we learn, among other things, that the vicinity of the house should be leeward and sunny, the vegetation should be healthy and lush while nearby rivers - if any - should flow along a gentle current. The preferred shape of both the plot and the house is rectangular or square. The windows of the building - already of a round shape - should preferably open outwards, which greatly facilitates the flow of good energy. In addition, each pair of doors must have at least three windows which also improves the atmosphere of the apartment. The entrance door should be wide and lead to a bright hallway, which, however, does not close to the rest of the property. Inside the house the proportions of room size are important. The size of the living room should not dominate over the size of the bedroom. You should also remember about the regular shape of the rooms, the appropriate height of the ceiling, and above all about order because the mess and a large number of unnecessary objects dim our energy. The way furniture is set up also has its own rules. Desks and beds must not be located in the middle of the room, it is advisable to add furniture to the wall. It is also not advantageous to expose ceiling beams in the house, they block the bloom of the ch'i. The art of feng shui is also used in bathrooms. The most important thing is not to place the sanitary facilities in front of the main entrance because there is a risk of literally flushing good energy along with water. The kitchen and a spacious dining room, on the other hand, should be located very close to 
each other. Moreover, it is good practice to place illustrations of food on the walls of these rooms (Webster R. 1998, p. 41-64). The above guidelines constitute only a small part of the whole philosophy but the studies for the whole art would be too extensive and impossible to show in the article.

The descriptions and advice provided by the feng shui idea are very detailed, but one thing is certain: in the life zone the colours, shapes and arrangement of objects are important. In the ideal place for existence all elements should be carefully balanced, there is no room for chance, illconsidered decisions and chaos. The modern world is far from green dragons and white tigers, but it is still possible to arrange the apartment according to the art of feng shui. Regardless of the stress and problems of everyday life, ubiquitous disorder and hustle and bustle, after returning home one should achieve blissful peace and positive energy flow. Continuous validity and popularity of ideas is connected with the fact that since the dawn of time man has been struggling with similar problems, constantly seeking harmony and peace. Numerous sources state about the substantial effectiveness and efficiency of philosophy.

\section{LE CORBUSIER'S VISIONS}

Le Corbusier, or rather Charles-Édouard Jeanneret-Gris was undoubtedly an outstanding architect and urban planner of the 20th century. Called the Pope of Modernism, he was able to seduce and convince generations of designers of his thoughts. He believed that architecture and design could not keep pace with the technological revolution of their time, and thus are not able to meet the needs of modern man. Thus he created a mass of concepts, theories and ready-made design solutions that would make up the canon of tomorrow's architecture. He never had a formal education, never graduated from an architectural school and yet he wrote 50 books in this field. The Prophet of New Architecture - this was one of the slogans advertising the Spanish edition of one of the architect's works - Towards an Architecture (Flint A. 2014, p. 4). Le Corbusier had an inexhaustible creative force and throughout his life and he carried out a veritable architectural revolution. He started modernism, especially purism and after World War II he became the father of brutalism.

Elegant, convinced of his genius and rightness as an architect drew inspiration from various places that he visited through the successive stages of his career, mainly during his travels around Europe. The Carthusian monastery in Val d'Ema which he visited as a young man stunned him. He combined all of Le Corbusier's most important features and was an ideal form of happy living. Situated on a hillside with a picturesque view of the rural landscape of Tuscany, it consisted of rooms with high ceilings and a small garden. Apart from private rooms there were also common areas for prayer and meals. Jeanneret described the very silhouette of the monastery as extremely noble [4]. Another example of inspiration was the transatlantic. A functionally organised ship with all of its amenities resembled a large residential building on the water. The interior of the ship was commented on by the architect as follows: (...) a wall full of windows, a bright room. What a contrast with the windows in our houses, piercing the wall in such a way that a shadow zone is created on each side, as a result of which the room becomes gloomy (...) (Le Corbusier 2012, p. 140). He wanted to erect its land-based counterpart, so perfectly proportional, flawless, pure and at the same time expressive. The interior of the bistro on rue Godot de Mauroy, where he often stayed at lunchtime also aroused strong emotions in Le Corbusier. The sparsely furnished room was long, narrow and deep. However, it seemed spacious thanks to the double height of the ceiling in one of the parts and the mezzanine on which the tables were located. The view from the balcony surrounding the building and the roof garden also met the architect's expectations. These are just some of the inspirations of Le Corbusier who intended to completely change the fate of architecture. For this purpose he created his own code of principles, which in his opinion must be fulfilled in order to implement an outstanding project. He formulated them in five points, showing how to make the most of the achievements of modern technology. First of all, a modern building must stand on reinforced concrete pillars (pilotis). Supports should raise the building to the height of at least one floor to provide space for communication, a garden and airflow. The second point is the obligation to have a flat roof. This solution, apart from its aesthetic advantages, has also a practical one - it allows for maximum use of space and allows to build a terrace or a garden on it. A third requirement is a free plan, i.e. moving away from small and cramped rooms to open spaces. Thanks to Le 
Corbusier's use of supports in the form of reinforced concrete columns it was even possible to completely give up walls. The fourth element, also made possible by the column structure, is the free façade. From now on the façade could be empty and smooth while the doors and windows could be subordinated to the concept and function instead of the structural requirements. Finally, the fifth element, which stems in a way from the fourth one, horizontally striped windows (preferably in dark frames) surrounding the entire building. Providing ideal illumination of the building as well as unobstructed views (Flint A. 2014, p. 54-55).
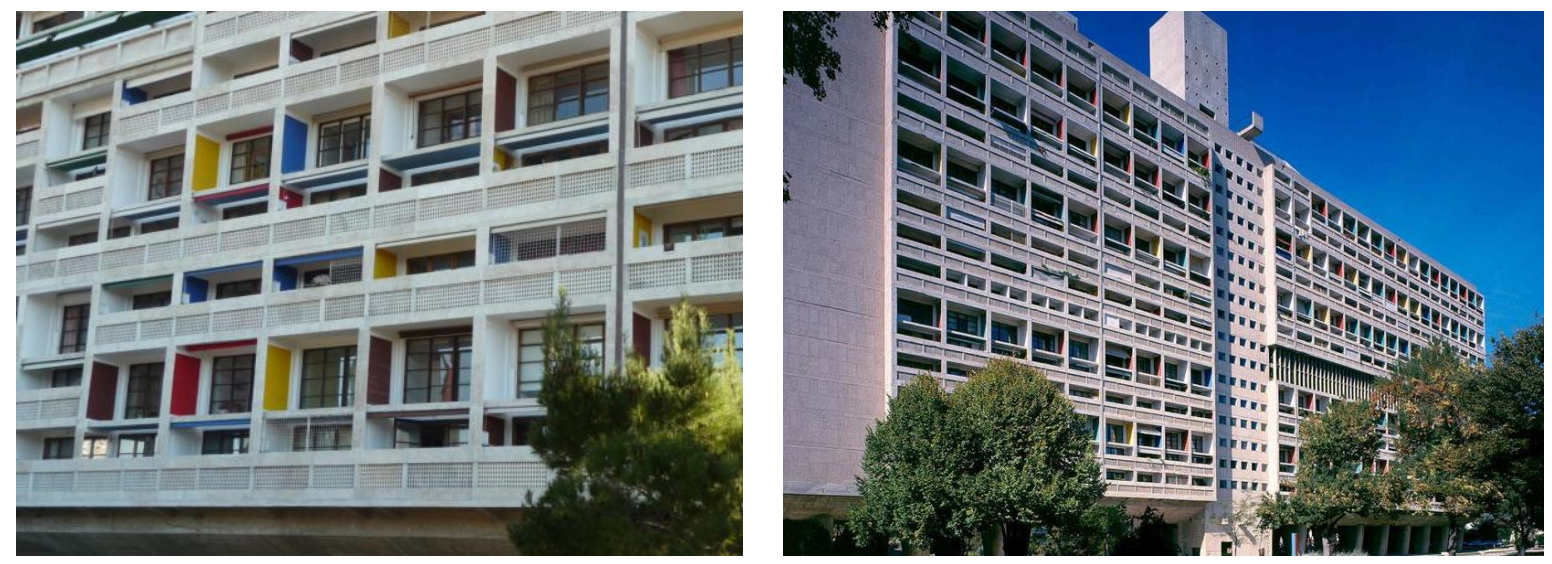

Fig. 1,2. Housing Unit, Marseille. Contemporary view. Source: Association des sites Le Corbusier, 2014

Ryc. 1,2. Jednostka Mieszkaniowa, Marsylia. Widok współczesny. Źródło: Association des sites Le Corbusier, 2014

Jeanneret broke the patterns of building both buildings and entire cities. He drew revolutionary, unprecedented forms, pure, smooth and white. Staircases were replaced by ramps and winding stairs, stone, brick and wood were replaced by concrete. When Le Corbusier's architectural bureau was at the height of its fame its range of services included the design of residential buildings including country houses, villas, shop windows and gardens as well as industrial buildings. While Le Corbusier's villas were undoubtedly works of art his thoughts were still obsessively directed towards multi-family housing in orderly and well-organised cities. As he claimed the house is a machine for living so his aspirations were directed towards repetitive residential buildings for the masses, built at low cost, surrounded by greenery and connected with each other by high-capacity expressways. The city was to become a calm, yet powerful, metropolis bathed in the light and abundance of fresh air. However, this vision was not possible to realize in the existing tight and dark quarters of the old city, the new city had to be built from scratch. The architect acted synthetically, combining architectural and urban aspects. He did not plan new buildings in an accidental, inappropriate place. His groundbreaking project - a vision of a new quality of life in the city - became the so-called Housing Unit (Unité d'Habitation), realized in Marseille. In the immediate vicinity of the city center stood a large, cuboidal, concrete block just over fifty meters high and one hundred and thirty-seven meters long (Fig. 2.). The whole building, unsurprisingly, was based on solid concrete poles. They not only supported the seventeen floor building but also allowed for free movement under the building towards parking lots as well as common spaces. In the Housing Unit there were three hundred and thirty-seven apartments of twenty-three different types. There were both bedsitters and larger flats for families with children (Flint A. 2014, p. 105-106). The flats were quite narrow but each of them was characterised by Le Corbusier's favourite double height ceilings. The floors were designed like blocks. Entrances to the flats were located on every second floor which enabled them to lead either to the mezzanine floor or directly to a larger space "on the space", i.e. to the building that was facing both sides (Fig. 3.). Thus, each of the residents had a possibility to ventilate the premises as well as a sufficient number of windows, allowing valuable daylight to enter and access to an invaluable view (Samuel F. 2007). Looking through huge windows, consisting of small glass panes set in dark, wooden frames, the landscape of mountains and the Mediterranean Sea stretched out before them. The apartments were also equipped with small balconies, allowing them to go outdoors with- 
out having to leave their homes. The interiors became the pride of Le Corbusier who opted for open spaces in accordance with principle 3 . The realisation of claustrophobic rooms was not in the style of an architect. The spaces seamlessly intertwined and passed from one room to another. $\mathrm{He}$ also resigned from heavy and spacious furniture in favour of recessed wardrobes and light chests of drawers. Shelves for books and art canons were also built into the wall at various points in the apartment. Le Corbusier often stressed that there must be room on the walls for valuable paintings, preferably original ones, but if someone cannot afford them he can easily replace them with reproductions (Le Corbusier 2012, p.160). Jeanneret also used simple wooden chairs with seats and braided rattan backrests, numerous lamps, both standing and wall lamps, and low benches (Fig. 11). The whole interior was a combination of raw concrete, warm wooden elements and clean white walls. What is characteristic for Le Corbusier is that the minimalist spaces were often decorated with unobvious patches of carefully selected colour. It was used to paint doors, letterboxes, pipes, balconies and window niches. Thanks to this both the interior of the building and the façade had red, yellow and blue elements. Besides the aesthetic dimension the Housing Unit was also designed for social purposes. The seventh floor of the building was used for services. There were shops, a laundry, post office, bar or hairdressing salon. There were also facilities such as a cinema and a kindergarten. The children's facility was located on the roof of the building and was equipped with a playground and a shallow paddling pool. Among the clouds adults could relax on concrete benches surrounded by tropical plants, play table tennis or basketball. In a word, it was an ideal place for recreation and meetings in a neighborhood. Unité d'Habitation combined luxury with functionality. It became a machine for living, from which one did not have to leave at all, an accumulation of all the functions necessary for human life (Flint A. 2014, p. 108-109).
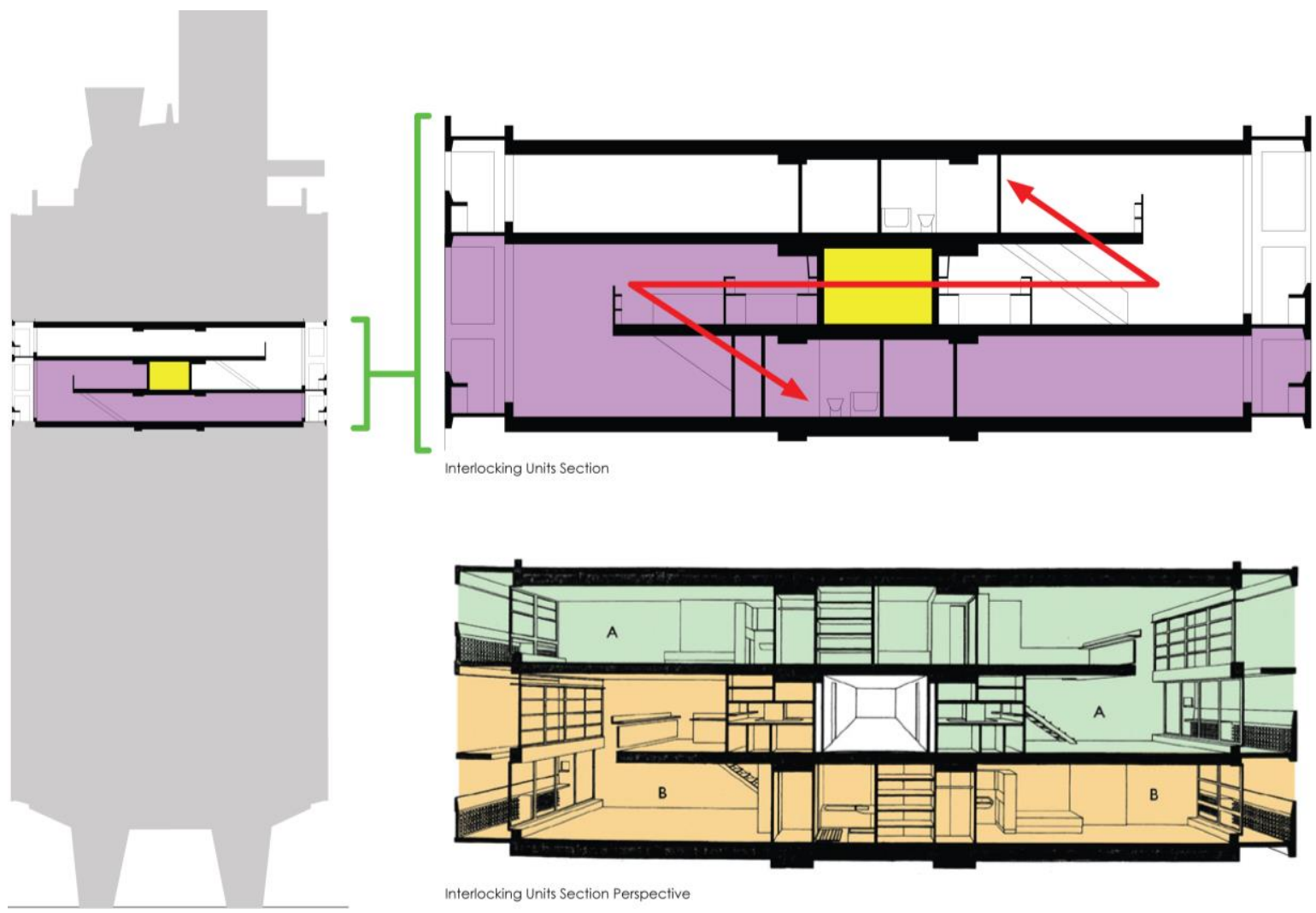

Interlocking Units Section Perspective

Fig. 3. Building section showing interlocking residential units. Source: 99\% Invisible, 2018.

Ryc. 3. Sekcja budynku pokazująca zazębiające się jednostki mieszkalne. Źródło: 99\% Invisible, 2018. 


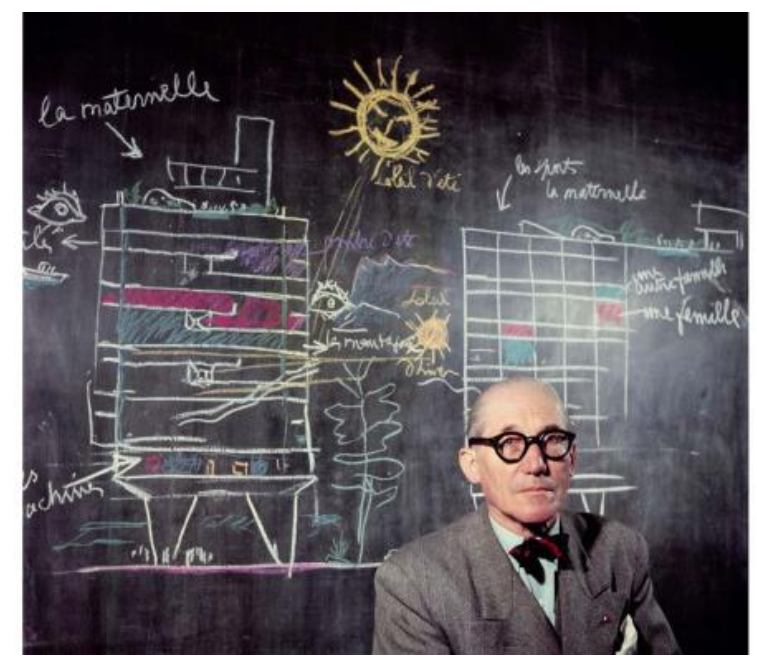

Fig. 4. Le Corbusier on the background of his drawing of the Housing Unit, 1949. Source: Greek Architects, 2012.

Ryc. 4. Le Corbusier na tle swojego rysunku Jednostki Mieszkaniowej, 1949 r. Źródło: Greek Architects, 2012.

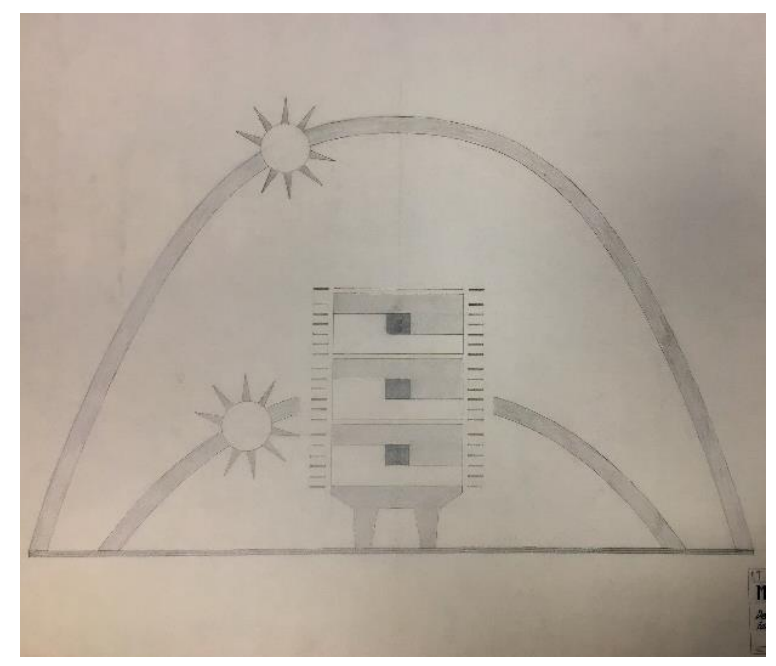

Fig. 5. Le Corbusier's drawing showing the path of the summer and winter sun in relations to the Unité, 1945. Source: Cohen J.L., 2008.

Ryc. 5. Rysunek Le Corbusiera ukazujący ścieżkę słońca w relacji do Jednostki Mieszkaniowej latem i zimą, 1945 r. Źródło: Cohen J.L., 2008.

\section{INNOVATORY NIGHTINGALE MODEL}

Nightingale is an innovative urban housing model that is socially, financially and environmentally sustainable. In the era when housing construction is mainly focused on the financial profits of the investor and not intangible benefits for people and the environment the above characteristics sound completely abstract. Fortunately however, there is a group of architects in Western Australia who want to break this infamous trend. They have created their own revolutionary philosophy, the overarching goal of which is to build a well-designed community run building for the owners, not the investors. The first, very important, step was to change the financial model. With the help of scientists and tax experts architects managed to develop one with zero profit and zero loss which made the difference between a project and a traditional investment. For this purpose it was preferable to use equity investors to raise funds. The architects from Melbourne personally controlled the budget and successfully convinced their colleagues in the industry of their idea. The enthusiasm of the architectural community translated into a considerable amount of money being raised for the project. Moreover, in order to maintain this trend the creators decided to sell flats only to owners who, in the event of a decision to sell the flat, agree to limit its price to the amount they paid (the difference can only be due to an increase in the average price of the property in the neighborhood). The sustainability of the project is also enhanced by its energy efficiency. Nightingale has a high energy rating, a nearly $70 \%$ reduction in heating and cooling costs, a solar photovoltaic system on the roof, and is also free of fossil fuels. This is not only environmentally friendly but also translates into significant annual savings. In addition, a bow to Mother Earth is being paid by moving away from the use of toxic materials in the construction process and introducing a water recycling system. The nuisances associated with cars have also been solved in a simple and incredibly effective way. Buyers are obliged to sign a contract in which they agree not to have "four wheels". The designers do not even assume the construction of parking spaces is necessary. It is suggested to replace cars with sustainable means of transport such as bicycles or public transport, which is only for the benefit of health and the environment (Gehl Blog, 2018). Especially since the buildings are perfectly connected with the rest of the city. The social dimension is another strength of the project. Formation of the community starts at the design stage. Throughout its duration public consultations are held during which future residents can share their suggestions, ideas and fears concerning the implementation. Additionally, the Nightingale objects offer generous common spaces such as a roof garden, a laundry room or a common room. The residents also have the opportunity to make contact with a wider 
community, e.g. during cyclical dinners in a neighborhood. The Nightingale buildings have also developed a trend towards active ground floors where retail tenants, catering and retail outlets are located. These solutions not only improve the attractiveness of the street but also significantly improve the quality and comfort of life of the residents (Brickworks, 2019).
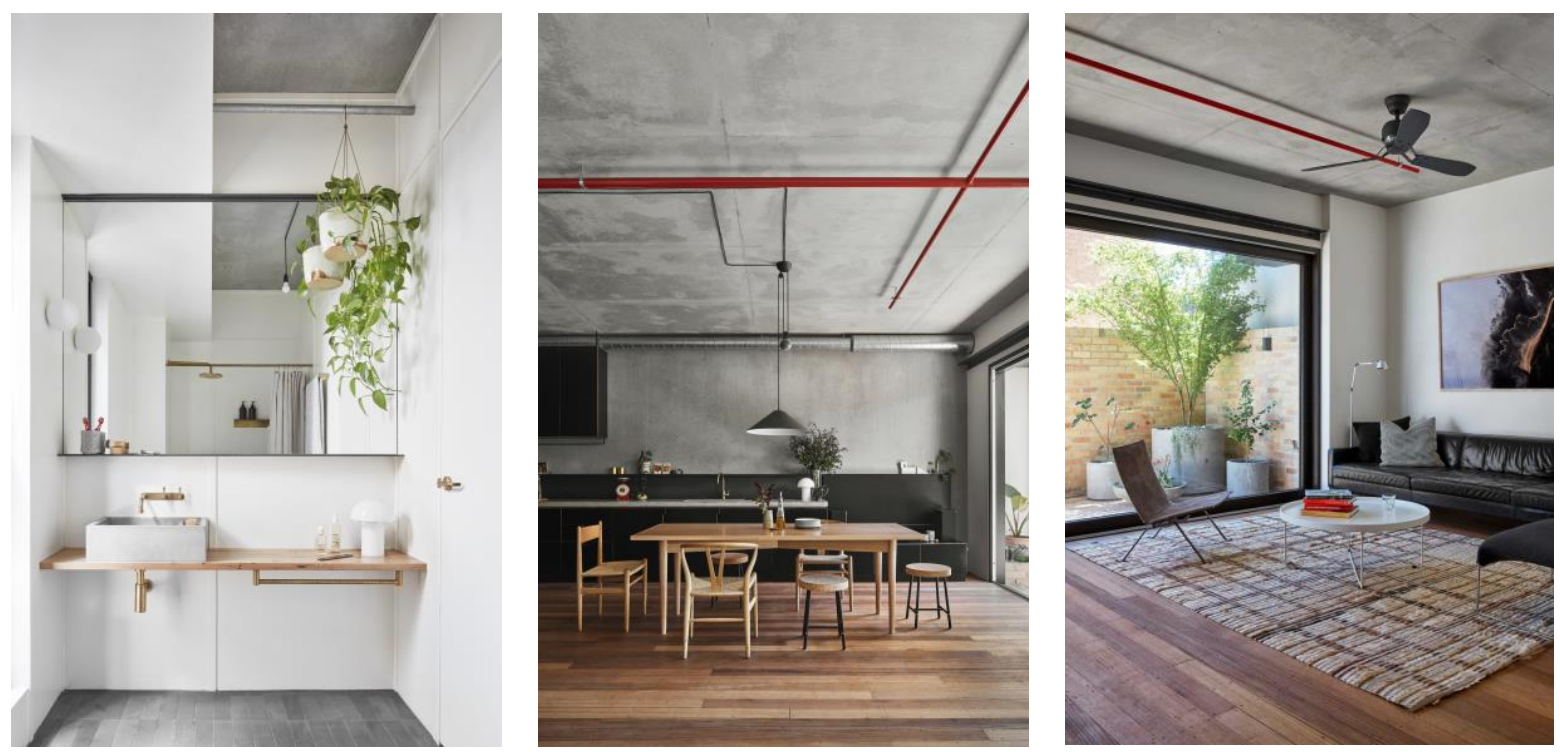

Fig. 6,7,8. Nightingale, interiors dominated by concrete, wood, earth colours. Source: Brickworks, 2019.

Ryc. 6,7,8. Nightingale, wnętrza zdominowane przez beton, drewno, kolory ziemi. Źródło: Brickworks, 2019.

One cannot be indifferent to the architecture of buildings either. Nightingale housing is characterized by simplicity, minimalism and purity of form. The dominant colours are earth colours and black, a large number of raw concrete elements, as well as scaled windows with anthracite muntin bars (Fig. 8, 10.). Spacious interiors are an architectural showcase combining the most fashionable decorative elements on the background of wooden furniture and floors, as well as concrete walls and ceilings. The whole is complemented by lush vegetation in vases and pots, emphasizing the natural and non-invasive character of the space. It is also impossible not to notice the sanitary and ventilation installations winding along the walls and ceilings (Fig. 7,8.). Their presence does not disturb the form of the interior but on the contrary adds charm and original character. All of the elements are balanced and compatible. It is worth noting that for each new concept of the Nightingale model a kind of standards book is created containing, among other things, broad descriptions of the investments, projections of flats and the materials with which they should be finished (Nightingale, What is...).

The main goal of the projects originators was to provide high quality and unique apartments at a reasonable price. The growing number of people interested in Nightingale premises and thus in ecological, ethical and community-based living can be seen as evidence of the achievement of this goal.

\section{SUMMARY}

The above descriptions indicate that ancient feng shui art, the views of the "father of modernism" and the fresh approach of the Nightingale model have much in common. In each of the three versions of the recipe for good space the key element is the access to light. Le Corbusier spoke directly about buildings bathed in the sun, according to feng shui, insufficient access to light is not recommended, and the large windows preferred in Nightingale allow plenty of sunlight into the raw interiors of the premises. What is important is the shape of the windows, their size, the colour of the 
frames, as well as which of the cardinal direction windows are facing. Le Corbusier's projects are dominated by huge ribbon glazing, embedded in steel or wooden frames in dark shades. In Marseille flats, they formed one of the walls of the interior, thus providing light to every corner of the premises. Additionally, it was important to expose the building to the east and west and the fact that all the apartments were designed in shotgun style. These factors provided access to light practically all day long regardless of the season (Fig. 5.).

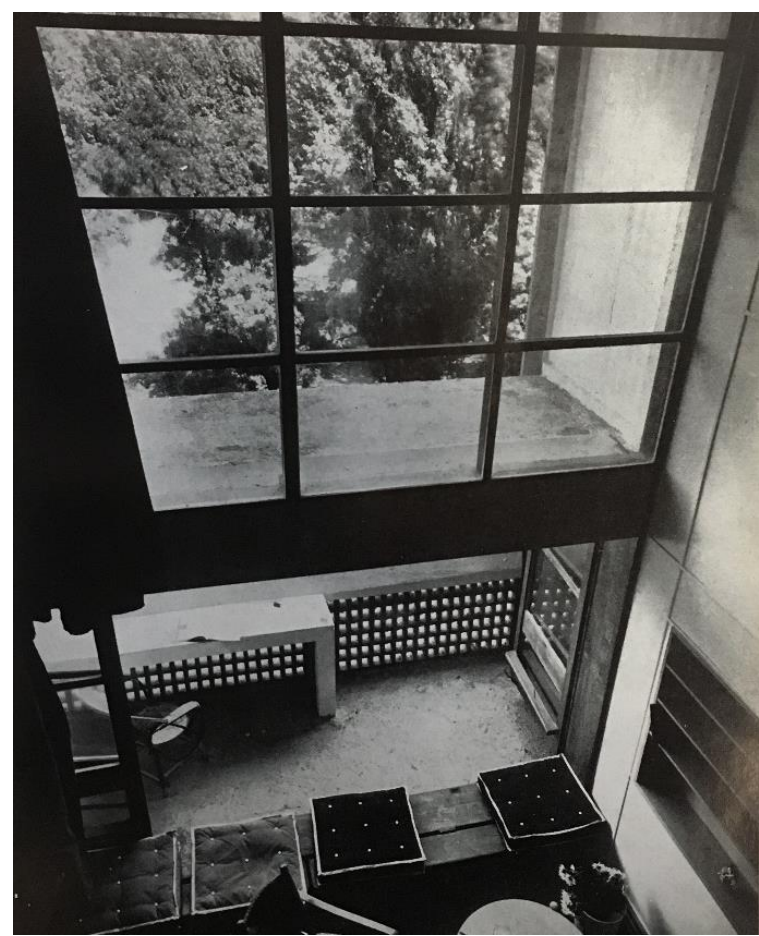

Fig. 9. The glass wall of the living-room in the Housing Unit, 1950. Source: Boesiger W., Girsberger H., Zurich, Editions Girberger, 1960.

Ryc. 9. Szklana ściana w salonie w Jednostce, 1950 r. Źródło: Boesiger W., Girsberger H., Zurich, Editions Girberger, 1960.

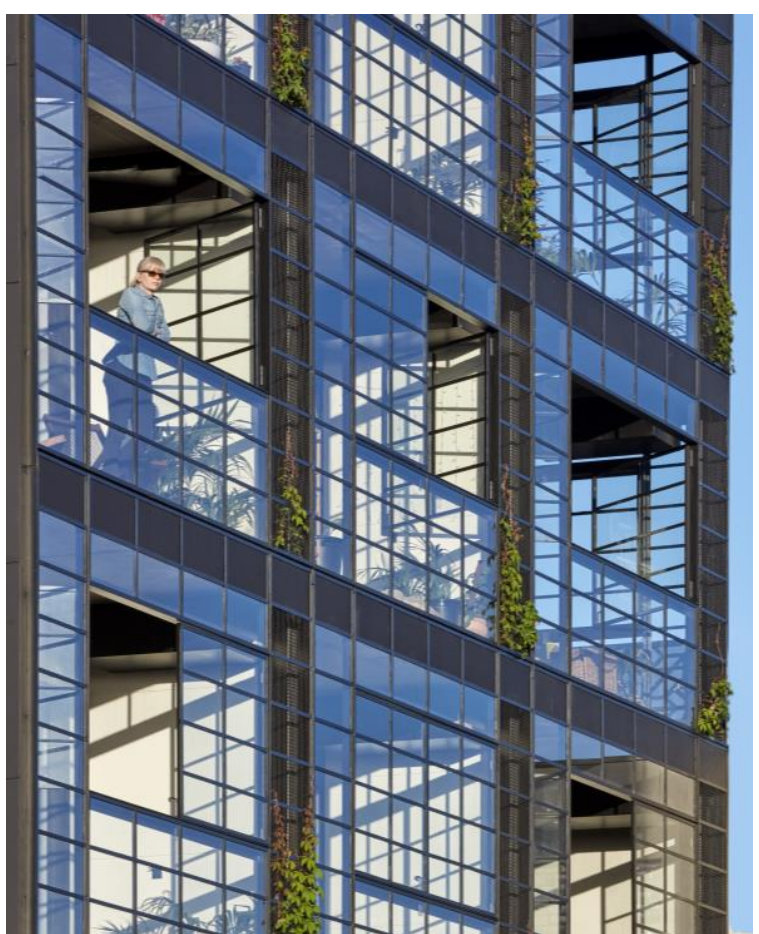

Fig. 10. Nightingale 1 - glass front façade. Source: Nightingale, Nightingale 1.

Ryc. 10. Nightingale 1 - szklana elewacja frontowa. Źródło: Nightingale, Nightingale 1.

The strategy of the authors of the Nightingale model is: To build more for less. Provide textures, space, height, light and air (Nightingale, House...). It can be seen that the last two words particularly resemble the views of the "father of modernism". In the case of the Australian model, only small open space apartments have windows to one side of the world, all larger apartments are realized as in Le Corbusier's case - in space, which of course favours light and gives the possibility of free airing (Cohen J.L., 2008). Another common feature is that the Nightingale buildings are dominated by large, rectangular windows embedded in solid, dark frames (Fig. 8,10.). The feng shui philosophy also emphasises the crucial role of light. It is even considered a cure, but only if its intensity and colour are right. The lack of light, too strong bulbs, the play of shadows, reflections, can cause serious emotional disturbances (Spear W. 1996, p.145). According to ancient philosophy, windows should also be wide enough to allow good energy to flow freely. However, arched or round windows are preferred, which is what distinguishes them from the other two theories. In addition, the colour of the frames should be different from the colour of the walls and thus provide a frame for the view outside the window (Feng Shui Windows) (Fig. 13.). At this point there is a strong analogy to Le Corbusier's view that every view must have its own frame (Flint A. 2014, p. 57), because what is a perfect interior in its essence if there is the ugliness, disorder, dirt and disorganization outside the window? The view calms and tunes down, completes the perfect interior. The architect has ar- 
ranged the interiors and even adjusted the furniture so that you can see as much as possible of what is outside the window. This is particularly true about the beds on the raised platform that Jeanneret used in his Paris apartment in Cabanon or in his parents' house - Maison Blanche (Flint A. 2014). At this point it is worth noting that the locations of his buildings were not random either. He always chose exceptional places for his buildings, with original and inspiring surroundings. In the case of feng shui, a lot of emphasis is also placed on the perception of the interior. The philosophy is that providing a wide field of vision inside the house gives a feeling of strength, security and peace (Spear W. 1996, p.97). Moreover, the aspect of the view from the bedside is also present. The mood while falling asleep determines what a man see while lying in bed. Therefore, it is important that the objects placed in the bedroom are aesthetic and harmonious, allowing for peace and tranquillity (Spear W. 1996, p.101). Colour is another important point of focus when comparing these three theories. Subdued colours and white dominate in feng shui. The more intense ones are used sporadically, in the form of minor accents (Spear W. 1996, p.179). The colour of accessories used in the apartment is influenced by the side of the world towards which the room is oriented, for example, in a living room facing south it is worth to place elements in warm shades red or yellow. Le Corbusier in the Housing Unit also used strong colours to accentuate the white walls, including cavity shelves in yellow, blue or red, which added individual character to the space. Similar colour motifs were used for the façade of the Unit. The balconies were treated with the basic colours (Fig. 1.). The Nightingale model also introduces strong colours in large measure, but each time on elements that cannot be overlooked, such as the red pipes leading through the ceiling (Fig. 7,8.). Despite the presence of colourful elements, each of the three philosophies is dominated by subdued earth tones and natural materials, the colour only emphasizes them and complements them. The interior design is another important aspect of the project. Le Corbusier designed the furniture himself and he introduced them into the apartments of the Housing Unit. Especially rattanwood and leather chairs and armchairs. This furniture had an original, minimalist and simple form (Fig. 11,12 .). Very similar elements are visible in the arrangements proposed by the originators of the Nightingale. Light wooden chairs with rattan seats and leather-covered sofas dominate. The rest of the furniture takes a very subtle and non-dominant form (Fig. 7,8,14). The feng shui interiors are complemented by simple furniture. It is important to position them in such a way that the flow of movement around them is undisturbed. They must not obstruct or block passageways. The focal point of every living room is the sofa and its location is crucial for the reception of the whole interior. It should not be too big and heavy, it is always worth to balance it with an element such as two chairs/pairs facing each other. It is also a good solution to move it away from the wall a bit, which will add lightness to the space (Beauchamp M. 2020) (Fig. 13.).

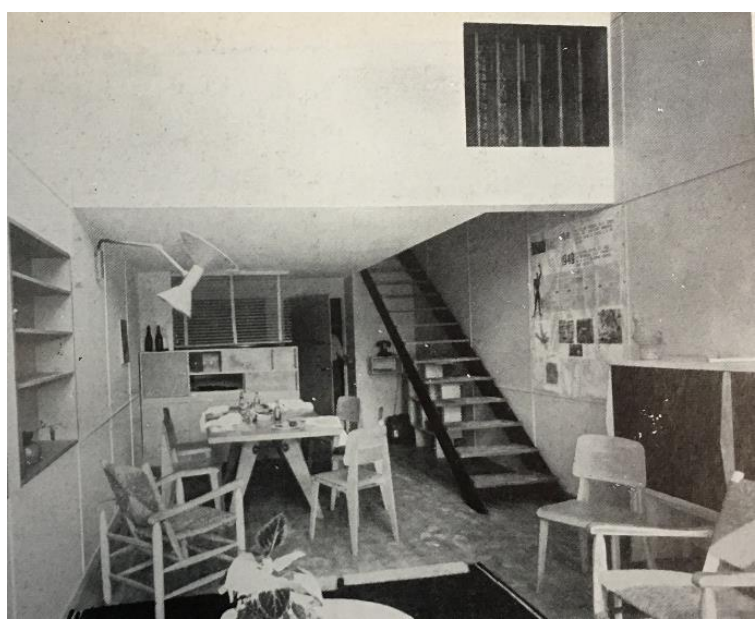

Fig. 11. Interior of a typical residential unit, 1950; Source: Boesiger W., Girsberger H., Zurich, Editions Girberger, 1960.

Ryc. 11. Wnętrze typowego lokalu mieszkalnego, $1950 \mathrm{r}$. Źródło: Boesiger W., Girsberger H., Zurich, Editions Girberger, 1960.

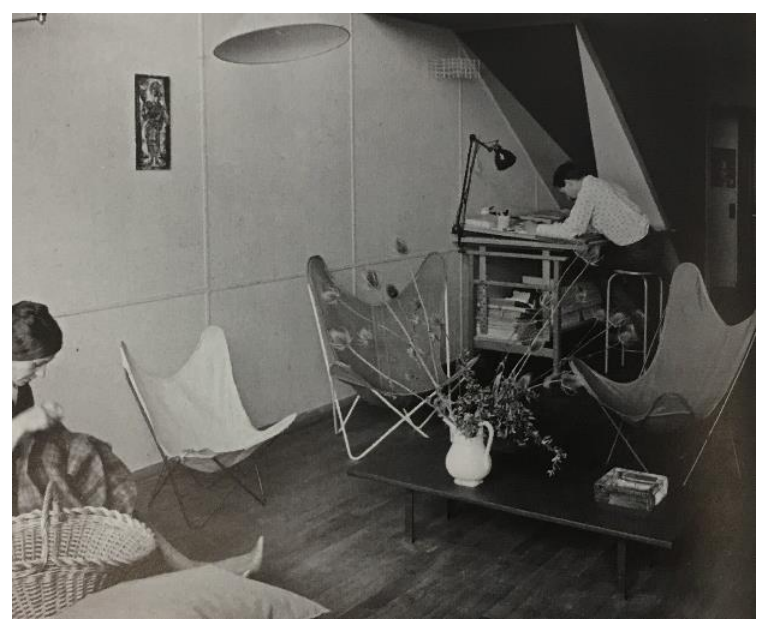

Fig. 12. Interior of a typical residential unit, 1952; Source: Cohen J.L., 2008.

Ryc. 12. Wnętrze typowego lokalu mieszkalnego, $1952 \mathrm{r}$. Źródło: Cohen J.L., 2008. 


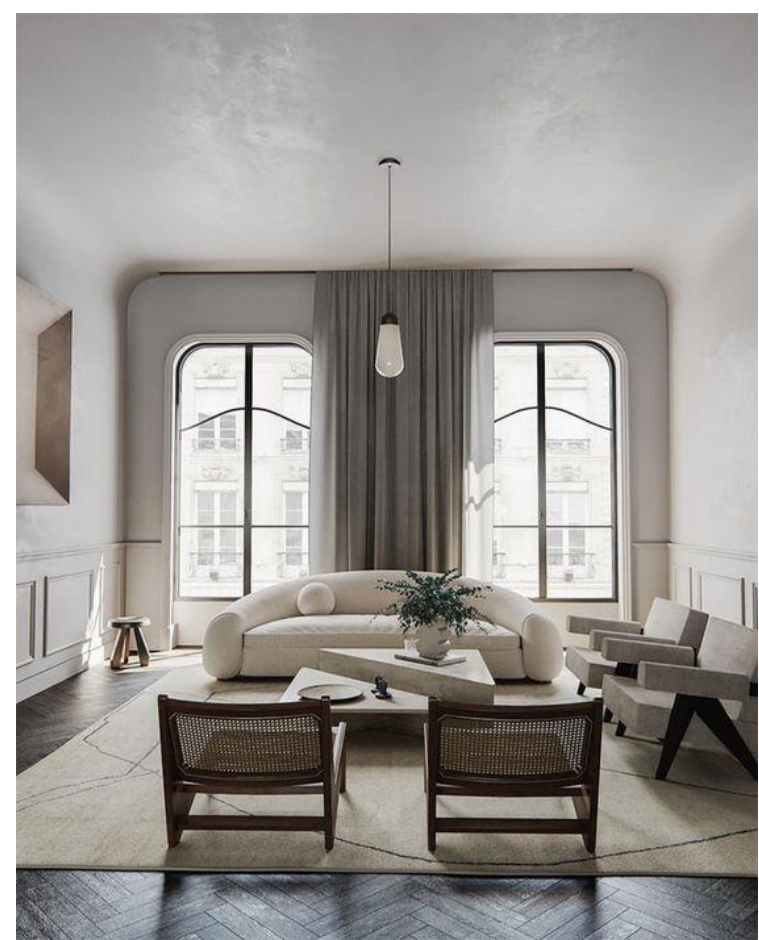

Fig. 13. Feng shui interior. Source: Dezign Ark, 2019.

Ryc. 13. Wnętrze zgodne z zasadami feng shui. Źródło: Dezign Ark, 2019.

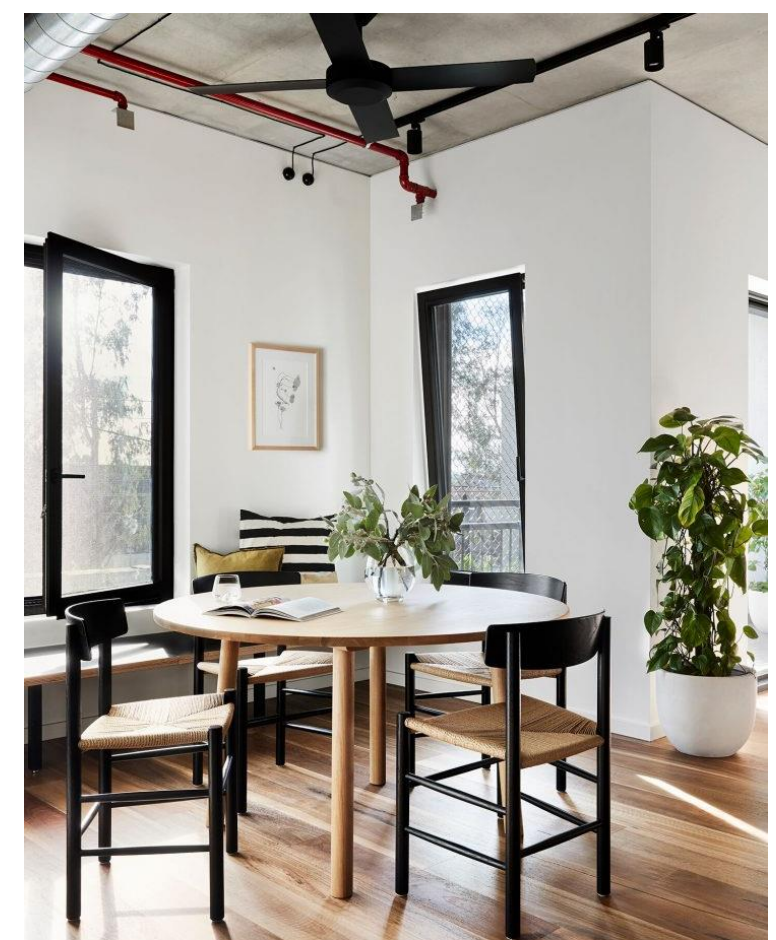

Fig. 14. Nightingale 2 - sample interior. Source: Nightingale, Nightingale 2 .

Ryc. 14. Nightingale 2 - przykładowe wnętrze. Źródło: Nightingale, Nightingale 2.

Another is simplicity, minimalism and order, understood in such a way that every object has its own specific place and should not be moved because a small reorganization of the interior can negatively affect the global perception of space. Le Corbusier even did not allow his wife Yvonne to modify their homes which met with her clear reluctance (Flint A. 2014, p. 195). In each of his interiors, considered in detail, there was no room for random objects or treatments. Similarities can also be found in the appearance of the buildings. Light, rectangular and square solids are preferred, without unnecessary surprises and a multitude of colours. Differences also exist, which was undoubtedly influenced by the epoch in which the views were formed. In the context of ancient China it is difficult to talk about the problem of increased car traffic and a shortage of parking spaces but in order to locate houses in relation to roads we will find precise guidelines. For Le Corbusier, however, automobiles were a very important element in the vision of a new lifestyle, inherent in the buildings he designed. It was supposed to be city-compatible if, of course, it was to be designed in such a way that it would be possible to communicate by this means of transport. The architect even created a prototype of his own model to complement his vision but the production never took place. In the case of Nightingale, there is a complete cut-off from the "four wheels" in favour of bicycles and public transport, among other things. Conscious contemporary designers aware of how much damage cars do, especially in cities, have not overlooked parking spaces in their projects. Housing estates with no access for cars are to become a salvation for the physical and mental health of the inhabitants. There are also a number of other similarities that characterize the Nightingale model and Le Corbusier's projects, but these are features for which it is difficult to find a common denominator with the homes of the ancient Chinese. These elements include the omnipresent concrete, Le Corbusier built entire houses from smooth cast concrete, and the Nightingale model also features walls, ceilings and floors made from this material. It is also worth mentioning the social dimension - the Housing Unit and its seventh floor full of service units, a roof with a kindergarten and a place for recreation (Fig. 16.), in the case of the Australian model cyclical meetings with neighbours, active ground floors with restaurants (accessible also to people from outside, in the Housing Unit only residents could use services) or a roof garden (Fig. 15.). 


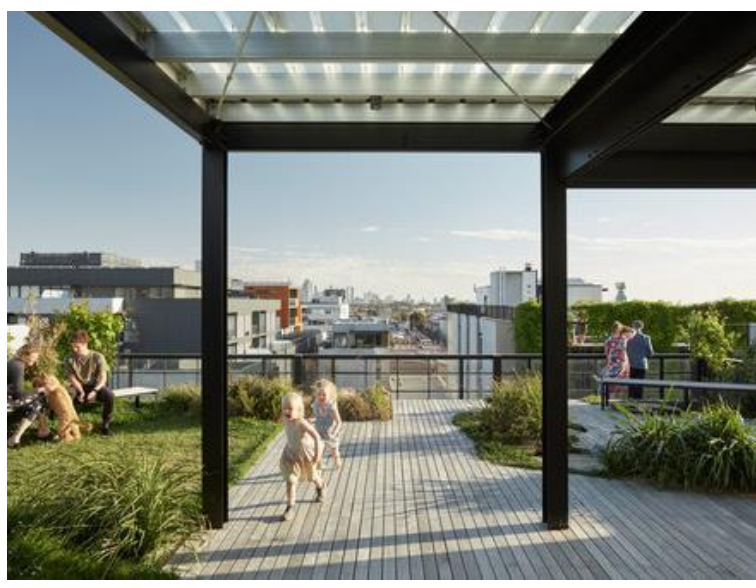

Fig. 15. Children playing on the rooftop of the Nightingale 1. Source: Nightingale, Nightingale 1.

Ryc. 15. Dzieci bawiące się na dachu Nightingale 1. Źródło: Nightingale, Nightingale 1.

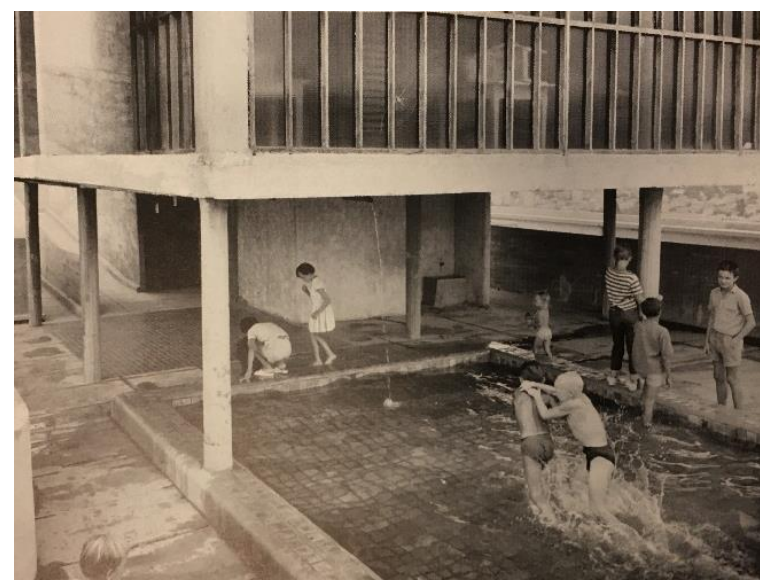

Fig. 16. Children playing on the rooftop of the Housing Unit, 1950. Source: Cohen J.L., 2008.

Ryc. 16. Dzieci bawiące się na dachu Jednostki Mieszkaniowej, 1950 r. Źródło: Cohen J.L., 2008.

The philosophy of feng shui is timeless, Le Corbusier revolutionized the approach to architecture, while the Nightingale model meets the trends of socially conscious housing construction. In the author's opinion, each of the three theories brings very important tips, which apartment to choose and how to organize it in order to improve the quality of life, achieve happiness, peace and balance.

Tab. 1. Summary of conclusions. Source: own study.

\begin{tabular}{|c|c|c|c|}
\hline Feature/subject & Feng shui philosophy & $\begin{array}{l}\text { Le Corbusier and Unité } \\
\text { d'Habitation }\end{array}$ & Nightingale model \\
\hline Access to light and air & $\begin{array}{l}\text { High role of light. It is even } \\
\text { considered a cure. }\end{array}$ & $\begin{array}{l}\text { Le Corbusier said that ac- } \\
\text { cess to light, fresh air, } \\
\text { space and greenery is cru- } \\
\text { cial (Le Corbusier, 2017). }\end{array}$ & $\begin{array}{l}\text { The strategy of the authors } \\
\text { of the Nightingale model is: } \\
\text { To build more for less. Pro- } \\
\text { vide textures, space, height, } \\
\text { light and air (Nightingale, } \\
\text { House...). }\end{array}$ \\
\hline $\begin{array}{l}\text { The size, type and color } \\
\text { of windows. The role of } \\
\text { the view and surround- } \\
\text { ings. }\end{array}$ & $\begin{array}{l}\text { The windows should be } \\
\text { wide enough to allow good } \\
\text { energy to flow freely. The } \\
\text { preferred shape is curved or } \\
\text { round. The color of the } \\
\text { frames should be different } \\
\text { from the color of the walls } \\
\text { and thus constitute a frame } \\
\text { for the view spreading out of } \\
\text { the window. }\end{array}$ & $\begin{array}{l}\text { Le Corbusier preferred huge } \\
\text { ribbon glazing, embedded in } \\
\text { steel or wooden frames in } \\
\text { dark shades. He always } \\
\text { chose exceptional places } \\
\text { with an original and inspir- } \\
\text { ing environment for his } \\
\text { buildings. }\end{array}$ & $\begin{array}{l}\text { Scaled rectangular windows } \\
\text { in anthracite frames domi- } \\
\text { nate, often over the whole } \\
\text { wall. Harmonious surroun- } \\
\text { dings are important. }\end{array}$ \\
\hline $\begin{array}{l}\text { Architectural form, used } \\
\text { materials, dominant } \\
\text { colors }\end{array}$ & $\begin{array}{l}\text { Simplicity, minimalism, sub- } \\
\text { dued colors and white are } \\
\text { valued. }\end{array}$ & $\begin{array}{l}\text { Concrete, minimalism and } \\
\text { purity are dominant. }\end{array}$ & $\begin{array}{l}\text { Simplicity, minimalism and } \\
\text { purity of form, earth colors } \\
\text { and black, large number of } \\
\text { raw concrete elements are } \\
\text { preferred. }\end{array}$ \\
\hline Greenery & $\begin{array}{l}\text { The greenery should be } \\
\text { healthy and lush. }\end{array}$ & $\begin{array}{l}\text { Access to light, fresh air, } \\
\text { space and greenery is cru- } \\
\text { cial (Le Corbusier, 2017). }\end{array}$ & $\begin{array}{l}\text { Inside the apartments there } \\
\text { are lush plants in vases and } \\
\text { pots. The façades are often } \\
\text { covered with ivy. }\end{array}$ \\
\hline The role of color accents & $\begin{array}{l}\text { Intensive colors are used } \\
\text { sporadically, in the form of } \\
\text { sparing accents. The color } \\
\text { of accessories used in the }\end{array}$ & $\begin{array}{l}\text { Le Corbusier in the Housing } \\
\text { Unit used strong colors to } \\
\text { emphasize the white walls, } \\
\text { among other things by using }\end{array}$ & $\begin{array}{l}\text { The Nightingale model in- } \\
\text { troduces strong colors with } \\
\text { a large measure, however, } \\
\text { each time on elements that }\end{array}$ \\
\hline
\end{tabular}




\begin{tabular}{|c|c|c|c|}
\hline & $\begin{array}{l}\text { apartment is influenced by } \\
\text { the side of the world on } \\
\text { which the room is oriented, } \\
\text { for example, in the living } \\
\text { room facing south it is worth } \\
\text { to place elements in warm } \\
\text { shades - red or yellow }\end{array}$ & $\begin{array}{l}\text { cavity shelves in yellow, } \\
\text { blue or red. }\end{array}$ & $\begin{array}{l}\text { cannot be overlooked, such } \\
\text { as the red pipes routed } \\
\text { through the ceiling. }\end{array}$ \\
\hline $\begin{array}{l}\text { Furniture arrangement } \\
\text { and type }\end{array}$ & $\begin{array}{l}\text { The feng shui interiors are } \\
\text { complemented by simple } \\
\text { furniture. It is important to } \\
\text { position them in such a way } \\
\text { that the flow of movement } \\
\text { around them is undisturbed. } \\
\text { They must not obstruct or } \\
\text { block passageways. The } \\
\text { focal point of every living } \\
\text { room is the sofa and its } \\
\text { location is crucial for the } \\
\text { reception of the whole inte- } \\
\text { rior. }\end{array}$ & $\begin{array}{l}\text { Le Corbusier introduced into } \\
\text { his apartments rattan-wood } \\
\text { and leather chairs and arm- } \\
\text { chairs of his project. The } \\
\text { furniture had an original, but } \\
\text { at the same time minimalist } \\
\text { and simple form. }\end{array}$ & $\begin{array}{l}\text { Light wood chairs with rat- } \\
\text { tan seats and leather- } \\
\text { covered sofas predominate. } \\
\text { The rest of the furniture } \\
\text { takes on a very subtle and } \\
\text { non-dominant form. }\end{array}$ \\
\hline Social dimension & $\begin{array}{l}\text { Feng shui does not refer } \\
\text { directly to social relations, } \\
\text { but rather to activities that } \\
\text { improve an individual's } \\
\text { energy and consequently } \\
\text { their relationship with other } \\
\text { people. }\end{array}$ & $\begin{array}{l}\text { The Housing Unit and its } \\
\text { seventh floor was full of } \\
\text { service premises. On the } \\
\text { roof there was a kindergar- } \\
\text { ten with a place for recrea- } \\
\text { tion. }\end{array}$ & $\begin{array}{l}\text { The public consultation } \\
\text { takes place already at the } \\
\text { design stage. Within the } \\
\text { buildings there are numer- } \\
\text { ous common spaces, regu- } \\
\text { lar dinners in the neighbor- } \\
\text { hood, as well as active first } \\
\text { floors. }\end{array}$ \\
\hline Role of the car & $\begin{array}{l}\text { It is difficult to relate this } \\
\text { aspect to an ancient philos- } \\
\text { ophy. }\end{array}$ & $\begin{array}{l}\text { Very important. Basing the } \\
\text { Unit on concrete poles al- } \\
\text { lowed to shorten the way to } \\
\text { parking lots. Le Corbusier } \\
\text { was fascinated by cars, he } \\
\text { designed his own model, } \\
\text { but it was not realized. }\end{array}$ & $\begin{array}{l}\text { Practically complete aban- } \\
\text { donment of the "four } \\
\text { wheels", promoting walking } \\
\text { and cycling. The authors do } \\
\text { not envisage parking lots } \\
\text { within the housing estates. }\end{array}$ \\
\hline
\end{tabular}

\section{W POSZUKIWANIU IDEALNEGO MIEJSCA DO ŻYCIA, OD FILOZOFII FENG SHUI, PORZEZ WIZJE LE CORBUSIERA I UNITÉ D'HABITATION, NA MODELU NIGHTINGALE SKOŃCZYWSZY}

\section{WSTĘP}

Dobre samopoczucie w domu jest jedną z podstawowych, głęboko zakorzenionych w człowieku potrzeb (Rybczyński W. 1996). Miejsce zamieszkania i pobytu ma ogromne przełożenie na jakość życia człowieka, na emocje, które odczuwa. Dom pełni różne funkcje - stanowi azyl, jest miejscem wytchnienia i odpoczynku, rozrywki, czasami pracy lub nauki, dlatego tym bardziej powinien leżeć w strefie ludzkiego komfortu. Czym jest jednak ów komfort i w jaki sposób można go osiągnąć? Pierwsze skojarzenie, które nasuwa się na myśl wielu ludziom, w kontekście komfortu w mieszkaniu, to komfort cieplny. Faktem jest, że to o tym uczą w szkołach, jest to także pierwsze skojarzenie wyszukiwarki Google’a, po wpisaniu hasła: komfort w domu. Idealna temperatura jednak wcale nie wystarczy, jeśli zaniedbamy inne, dużo ważniejsze, sfery. Jakie zatem czynniki determinują idealne miejsce do życia? Czy istnieje uniwersalny kanon wytycznych?

Niniejszy artykuł traktuje o trzech na pozór zupełnie różnych teoriach, posiadających jednak wspólny mianownik - każda z nich stanowi swego rodzaju receptę na idealne - według autorów - miejsce do życia. Celem głównym artykułu jest wskazanie podobieństw i kontrastów wybranych wizji 
poprzez analizę zagadnień, ich rozpoznanie w kontekście wybranego zespołu cech odnoszących się głównie do architektury, aranżacji wnętrza, aspektu społecznego oraz otoczenia.

\section{FILOZOFIA FENG SHUI}

Od starożytności w Chinach znana jest filozofia feng shui, która sprowadza się do sztuki harmonijnego obcowania z otoczeniem. Chińczycy wierzyli w silną korelację pomiędzy losami ludzi, a miejscem ich przebywania na ziemi. Według twierdzeń w świecie istnieje równowaga i porządek, a człowiek za sprawą odpowiednich działań jest w stanie przyciągnąć do siebie pozytywną energię (ch'i). Filozofia ta niegdyś nie była jedynie sposobem na życie, ale także poniekąd na śmierć, ponieważ czynność jak wybieranie miejsca pochówku musiała również być zgodna ze sztuką. Współcześnie feng shui stało się nieco dopasowane do kultury zachodniej i zajmuje się głównie energią oraz harmonią przyrody, która ma za zadanie zrównoważenie sił życiowych człowieka, mających przełożenie na jego przeznaczenie. Istotą filozofii jest logika, to narzędzie pozwala dostrzec człowiekowi jaki wpływ na jego losy ma otoczenie, w którym przebywa. Osiągnięcie tej świadomości prowadzi do poprawy jakość przestrzeni życiowej w jego domu czy w pracy. Komfort i zdrowa atmosfera energetyczna, natomiast przybliża ludzi do osiągnięcia sukcesu we wszystkich dziedzinach życia (Gęsiarz M. 2009, s. 13-17).

Sztuka feng shui to bardzo obszerne zagadnienie, o czym świadczy między innymi fakt, że na przestrzeni pięciu tysięcy lat od momentu powstania filozofii, pojawiło się kilka, na pozór przeciwstawnych, systemów: Szkoła Form, Szkoła Intuicyjna czy Szkoła Kompasu. Szczególnie interesujące są założenia Szkoły Form, która bazowała przede wszystkim na obserwacji różnych form krajobrazu i ich wpływie na otoczenie. Wprowadziła odpowiedniki ukształtowania terenu w postaci zwierząt, a każda ingerencja człowieka w przestrzeń musiała być zgodna z filozofią i nie zaburzać równowagi panującej w danej okolicy. Zalecenia tego systemu dotyczyły zarówno lokalizacji domu, jego kształtu, jak również aranżacji wnętrza. Szczegółowe wytyczne odnoszą się między innymi do okolicy domu, która powinna być zawietrzna i dobrze nasłoneczniona, do roślinności - zdrowa i bujna, oraz do pobliskich rzek (jeśli istnieją), które powinny płynąć łagodnym nurtem. Preferowany kształt zarówno parceli jaki i domu to prostokąt lub kwadrat. Okna budynku - już o obłym kształcie - najlepiej by otwierały się na zewnątrz, co znacznie ułatwiało przepływ dobrej energii. Dodatkowo, każdej parze drzwi muszą odpowiadać przynajmniej trzy okna, to również poprawia atmosferę mieszkania. Drzwi wejściowe dobrze by były szerokie i prowadziły do jasnego przedpokoju, który jednak nie zamyka się na resztę posesji. We wnętrzu domu ważne są proporcje wielkości pomieszczeń. Rozmiar salonu nie powinien zbytnio dominować nad wielkością sypialni. Należy także pamiętać o regularnym kształcie pomieszczeń, odpowiedniej wysokości sufitu, a przede wszystkim o porządku, bo bałagan i duża ilość zbędnych przedmiotów przygaszają energię. Sposób ustawienia mebli też ma określone zasady. Biurka i łóżka nie wolno lokalizować pośrodku pokoju, wskazane jest dostawianie mebla do ściany. Nie korzystne jest także eksponowanie belek stropowych w domu, blokują one rozkwit ch'i. Sztuka feng shui ma swoje zastosowanie również w łazienkach. Najważniejsze żeby nie umieszczać sanitariatów naprzeciwko drzwi wejściowych, istnieje bowiem ryzyko dosłownego spłukania dobrej energii wraz z wodą. Kuchnia i przestronna jadalnia powinny być zlokalizowanej bardzo blisko siebie. Co więcej, dobrą praktyką jest umieszczanie na jej ścianach ilustracji przedstawiających pożywienie (Webster R. 1998, s. 41-64). Powyższe wytyczne, stanowią jedynie małą część całej filozofii, jednak studia nad całą sztuką byłyby zbyt obszerne i niemożliwe do ukazania na łamach artykułu.

Opisy i porady niesione przez ideę feng shui są bardzo szczegółowe, jednak jedno jest pewne, w strefie życia ważne są kolory, kształty oraz sposób rozmieszczenia przedmiotów. W idealnym miejscu do egzystencji wszystkie elementy powinny być starannie zbilansowane, nie ma tam miejsca na przypadek, nieprzemyślane decyzje i chaos. Współczesny świat daleki jest od zielonych smoków i białych tygrysów, jednak wciąż możliwa jest aranżacja mieszkania zgodnie ze sztuką feng shui. Bez względu na stres i problemy życia codziennego, wszechobecny nieład i zgiełk, po powrocie do domu powinno się osiągać błogi spokój i napływ pozytywnej energii. Nieustająca aktualność i popularność idei ma związek z faktem, że człowiek od zarania dziejów boryka się z podobnymi problemami i nieustannie poszukuje harmonii i spokoju. Liczne źródła podają o niebagatelnej skuteczności i efektywności filozofii. 


\section{LE CORBUSIERA I JEGO WIZJA}

Le Corbusier, a właściwie Charles-Édouard Jeanneret-Gris, był niewątpliwie wybitnym architektem i urbanistą XX w. Nazywany papieżem modernizmu potrafił uwieść i przekonać do swoich myśli całe pokolenia projektantów. Uważał, że architektura oraz wzornictwo nie nadążają za rewolucją techniczną swoich czasów, a co za tym idzie nie są w stanie sprostać potrzebom nowoczesnego człowieka. Stworzył więc masę pojęć, teorii, a także gotowych rozwiązań projektowych składających się na kanon architektury jutra. Nigdy nie posiadł formalnego kierunkowego wykształcenia, nie skończył szkoły architektonicznej, a mimo to napisał 50 książek w tej dziedzinie. Prorok nowej architektury - tak brzmiał jeden ze sloganów reklamujących hiszpańskie wydanie jednego z dzieł architekta - W stronę architektury (Flint A. 2014, s. 4). Le Corbusier miał niespożyte siły twórcze, przez całe swoje życie dokonywał istnej rewolucji architektonicznej. Zapoczątkował modernizm, szczególnie puryzm, a po II wojnie światowej stał się ojcem brutalizmu.

Wytworny, przekonany o swoim geniuszu oraz słuszności racji architekt, czerpał inspiracje z różnych miejsc, które spotykał na swojej drodze na kolejnych etapach kariery, głównie w trakcie podróży po Europie. Klasztor kartuzów w Val d’Ema, który odwiedził jako młodzieniec wprawił go w osłupienie. Łączył w sobie wszystkie najważniejsze dla Le Corbusiera cechy, był idealną formą szczęśliwego mieszkania. Posadowiony na zboczu, z którego rozpościerał się malowniczy widok na wiejski krajobraz Toskanii, składał się z pomieszczeń o wysokich sufitach i małego ogrodu. Oprócz prywatnych izdebek, znajdowały się tam również przestrzenie wspólne do modlitwy i posiłków. Samą sylwetkę klasztoru Jeanneret określił jako niesamowicie szlachetną [4]. Innym przykładem inspiracji stał się transatlantyk. Funkcjonalnie zorganizowany statek ze wszystkimi udogodnieniami przypominał wielki budynek mieszkalny na wodzie. Wnętrze statku architekt skomentował w następujący sposób: (...) ściana cała w oknach, jasna sala. Cóż za kontrast z oknami w naszych domach, przebijającymi mur w taki sposób, że z każdej strony powstaje strefa cienia, w skutek czego pomieszczenie staje się ponure (...) (Le Corbusier 2012, s. 140). Chciał wznieść jego odpowiednik na lądzie, tak idealnie proporcjonalny, bezbłędny, czysty, a zarazem wyrazisty. Silne emocje wzbudziło w Le Corbusierze także wnętrze bistro na rue Godot de Mauroy, gdzie często przebywał w porze obiadowej. Oszczędnie umeblowane pomieszczenie było długie, wąskie i głębokie. Sprawiało jednak wrażenie przestronnego dzięki podwójnej wysokości sufitu w jeden z części i antresoli, na której znajdowały się stoliki. Widok z balkonu okalającego budynek oraz ogrodu na dachu również spełniał oczekiwania architekta. To tylko niektóre z inspiracji Le Corbusiera, który to miał zamiar całkowicie odmienić losy architektury. W powyższym celu, stworzył własny kodeks zasad, które w jego ocenie należy spełnić aby zrealizować wybitny projekt. Sformułował je w pięciu punktach, ukazując jak maksymalnie można wykorzystać zdobycze nowoczesnej techniki. Po pierwsze, współczesny, nowoczesny budynek musi stać na żelbetowych słupach (pilotis). Podpory powinny unosić budynek na wysokość minimum jednego piętra, tak aby uzyskać przestrzeń na komunikację, ogród oraz wspomóc przewiew powietrza. Drugi punkt, to obowiązek realizacji płaskiego dachu. To rozwiązanie oprócz zalet estetycznych, ma też praktyczne - pozwala maksymalnie wykorzystać przestrzeń, zrealizować na nim taras lub ogród. Kolejny - trzeci wymóg to wolny plan, czyli odejście od małych i ciasnych pokoi na rzecz przestrzeni otwartych. Dzięki zastosowaniu przez Le Corbusiera podpór w postaci słupów żelbetowych, możliwa była nawet całkowita rezygnacja ze ścian. Czwarty element, także możliwy dzięki konstrukcji słupowej, to wolna elewacja. Odtąd elewacja mogła pozostać pusta i gładka, a drzwi i okna być podporządkowane koncepcji i funkcji, zamiast wymogom konstrukcyjnym. Aż wreszcie piąty element, wynikający poniekąd z czwartego - poziome okna pasmowe - najlepiej w ciemnych framugach - otaczające cały budynek. Zapewniające idealne doświetlenie budynku, jak również nie zaburzone niczym widoki (Flint A. 2014, s. 54-55).

Jeanneret przełamywał schematy w zakresie wznoszenia zarówno budynków, jak i całych miast. Kreślił rewolucyjne, niespotykane dotąd formy - czyste, gładkie, białe. Klatki schodowe zastępował rampami i kręconymi schodami, a kamień, cegłę i drewno betonem. Kiedy biuro architektoniczne Le Corbusiera było u szczytu sławy, zakres jego usług obejmował projekty: budynków mieszkalnych, w tym domów wiejskich, willi, witryn sklepowych, ogrodów, jak również obiektów dla przemysłu. O ile to właśnie wille Le Corbusiera były niewątpliwymi dziełami sztuki, jego myśli były wciąż obsesyjnie skierowane w stronę budownictwa mieszkaniowego wielorodzinnego, w uporządkowa- 
nych i dobrze zorganizowanych miastach. Jak twierdził - dom jest maszyną do mieszkania, jego dążenia zatem były skierowane w kierunku powtarzalnych budynków mieszkalnych dla mas, wznoszonych tanimi kosztami, w otoczeniu zieleni, połączonych ze sobą trasami szybkiego ruchu o dużej przepustowości. Miasto miało stać się spokojną, a zarazem potężną metropolią, skąpaną w świetle i obfitości świeżego powietrza. Wizja ta nie była jednak możliwa do realizacji w istniejących ciasnych i ciemnych kwartałach. Nowe miasto musiało powstać od podstaw. Architekt działał syntetycznie, łączył aspekty architektoniczne z urbanistycznymi. Nie planował nowych budynków w przypadkowym, nieodpowiednim miejscu. Jego przełomowym projektem - wizją nowej jakości życia w mieście - stała się tzw. Jednostka Mieszkaniowa (Unité d'Habitation), zrealizowana w Marsylii. W niedalekim sąsiedztwie centrum miasta stanęła wielka, betonowa prostopadłościenna bryła, mająca nieco ponad pięćdziesiąt metrów wysokości i sto trzydzieści siedem metrów długości (Ryc. 2.) Całość, co nie jest zaskoczeniem, opierała się na solidnych betonowych słupach. Stanowiły one nie tylko oparcie dla siedemnastopiętrowej budowli, ale pozwoliły także na swobodny ruch pod budynkiem - w stronę parkingów, jak również przestrzeni wspólnych. W Jednostce Mieszkaniowej można było wyróżnić trzysta trzydzieści siedem mieszkań, dwudziestu trzech odmiennych typów. Do wyboru były zarówno kawalerki, jak i większe lokale dla rodzin z dziećmi (Flint A. 2014, s. 105-106). Mieszkania były dość wąskie, jednak każde charakteryzowała ulubiona przez Le Corbusiera - podwójna wysokość. Kondygnacje zostały zaprojektowane niczym klocki. Wejścia do mieszkań znajdowały się na co drugim piętrze i dzięki temu mogły prowadzić albo na antresolę, albo wprost do większej przestrzeni „na przestrzał”, czyli wychodzącej na obie strony budynku (Ryc. 3.). Tym samym każdy z mieszkańców miał zapewnioną możliwość przewietrzenia lokalu, jak i odpowiednią liczbę okien wpuszczających tak cenne światło dzienne, a także dostęp do nieocenionego widoku (Samuel F. 2007). Wyglądając przez ogromne okna, składające się z niewielkich szyb osadzonych w ciemnych, drewnianych ramach, rozpościerał się krajobraz gór i Morza Śródziemnego. Mieszkania były także wyposażone w nieduże balkony, pozwalające na przebywanie na świeżym powietrzu bez potrzeby opuszczania domu. Wnętrza stały się dumą Le Corbusiera, który zgodnie z zasadą numer trzy postawił na przestrzenie otwarte. Realizowanie klaustrofobicznych pokoików nie było w stylu architekta. Przestrzenie płynnie się ze sobą łączyły i przechodziły jedna w drugą. Zrezygnował także z ciężkich i zajmujących dużo miejsca mebli, na rzecz szaf wnękowych i lekkich komód na nogach. Półki na książki i dzieła sztuki również zostały wbudowane w ścianę w różnych punktach mieszkania. Le Corbusier często podkreślał, że na ścianach musi być miejsce na wartościowe obrazy, najlepiej oryginalne, jednak jeśli kogoś na to nie stać, może swobodnie zastąpić je reprodukcjami (Le Corbusier 2012, s. 160). Jeanneret zastosował także proste drewniane krzesła swojego projektu z siedziskami oraz oparciami z plecionego rattanu, liczne lampy - stojące, jak i ścienne, oraz niskie ławy. Całość wnętrza stanowiła połączenie surowości betonu, ciepła drewnianych elementów z czystością białych ścian (Ryc. 11.). Co jest charakterystyczne dla Le Corbusiera, minimalistyczne przestrzenie zdobiły często nieoczywiste plamy starannie dobranego koloru. Użyto go do pomalowania drzwi, skrzynek na listy, rur, balkonów oraz nisz okiennych. Dzięki temu, zarówno wnętrze budynku jak i fasada posiadały czerwone, żółte i niebieskie elementy. Oprócz wymiaru estetycznego, Jednostka Mieszkaniowa była także zaprojektowana pod kątem społecznym. Siódme piętro budynku zostało przeznaczone pod usługi. Znajdowały się tam między innymi: sklepy, pralnia, poczta, bar czy salon fryzjerski. Nie zabrakło także udogodnień jak kino oraz przedszkole. Placówka dla dzieci została zlokalizowana na dachu budynku i wyposażona była w plac zabaw oraz płytki brodzik. Wśród chmur dorośli mogli odpoczywać na betonowych ławkach w otoczeniu ogrodu tropikalnych roślin, grać w tenisa stołowego czy koszykówkę. Słowem, było to idealne miejsce do rekreacji i spotkań w sąsiedzkim gronie. Unité d'Habitation łączyła w sobie luksus z funkcjonalnością. Stała się maszyną do mieszkania, z której w ogóle nie trzeba było wychodzić, kumulacją wszystkich funkcji potrzebnych do życia człowiekowi (Flint A. 2014, s. 108-109).

\section{NOWATORSKI MODEL NIGHTINGALE}

Nightingale to nowatorski model mieszkalnictwa miejskiego, zrównoważony pod względem społecznym, finansowym i środowiskowym. W dobie, kiedy budownictwo mieszkaniowe jest głównie ukierunkowane na zyski finansowe inwestora, a nie korzyści niematerialne dla ludzi i środowiska, powyższa charakterystyka brzmi zupełnie abstrakcyjnie. Na szczęście jednak w Australii Zachod- 
niej znalazła się grupa architektów chcąca przełamać ten niechlubny trend. Stworzyli oni własną rewolucyjną filozofię, której celem nadrzędnym jest budowa dobrze zaprojektowanego, prowadzonego przez społeczność budynku, dla właścicieli, a nie inwestorów. Pierwszym, bardzo ważnym krokiem okazała się być zmiana modelu finansowego. Z pomocą naukowców i ekspertów podatkowych, architekci zdołali opracować taki o zerowym zysku i stracie, co szczególnie odróżniło projekt od tradycyjnych inwestycji. W tym celu preferowane było wykorzystanie inwestorów kapitałowych do pozyskania funduszy. Architekci z Melbourne osobiście sprawowali kontrolę nad budżetem i szczęśliwie zdołali przekonać kolegów z branży do swojej idei. Zachwyt środowiska architektów przełożył się na zebranie znacznej sumy pieniędzy, niezbędnej do realizacji projektu. Co więcej, twórcy chcąc utrzymać ww. trend, postanowili sprzedawać mieszkania tylko właścicielom, którzy w przypadku podjęcia decyzji o pozbyciu się lokalu, wyrażają zgodę na ograniczenie jego ceny do kwoty, którą sami zapłacili (różnica może wynikać jedynie z podwyżki średniej ceny nieruchomości w sąsiedztwie). Zrównoważonego charakteru projektowi dodaje także jego energooszczędność. Nightingale ma wysoką ocenę energetyczną, zbliżoną do $70 \%$ redukcję kosztów ogrzewania i chłodzenia oraz słoneczny system fotowoltaiczny na dachu, a także jest wolne od paliw kopalnych. Powyższe nie tylko jest przyjazne środowisku, ale także przekłada się na znaczne oszczędności finansowe w skali roku. Dodatkowo, ukłon Matce Ziemi oddawany jest poprzez odejście w procesie budowlanym od użycia toksycznych materiałów, a także wprowadzenie systemu odzyskiwania wody. Uciążliwości związane z samochodami również zostały rozwiązane w prosty i niesamowicie skuteczny sposób. Kupujący mieszkanie są zobowiązani podpisać umowę, w której godzą się na nieposiadanie „czterech kółek”. Projektanci nawet nie zakładają budowy miejsc parkingowych. Sugeruje się wymianę aut na zrównoważone środki transportu - rowery czy transport publiczny, co jest jedynie z korzyścią dla zdrowia, jak i środowiska (Gehl Blog, 2018). Tym bardziej, że budynki są doskonale skomunikowane $z$ resztą miasta.

Wymiar społeczny, to kolejna mocna strona projektu. Formowanie społeczności zaczyna się już na etapie projektowym. Przez cały okres jego trwania odbywają się konsultacje społeczne, podczas których przyszli mieszkańcy mogą dzielić się swoimi sugestiami, pomysłami czy obawami dotyczącymi realizacji. Dodatkowo, obiekty modelu Nightingale oferują obfite przestrzenie wspólne, takie jak własny ogród na dachu, pralnia czy świetlica. Mieszkańcy mają także możliwość nawiązania kontaktu z szerszą społecznością, np. podczas organizowanych cyklicznie kolacji w sąsiedzkim gronie. W budynkach Nightingale rozwinął się także trend realizacji aktywnych parterów, gdzie mieszczą swoje siedziby detaliczni najemcy, prowadzący lokale o charakterze gastronomicznym czy handlowym. Rozwiązania te nie tylko poprawiają atrakcyjność ulicy, ale również znacznie polepszają jakość i komfort życia mieszkańców (Brickworks, 2019).

Nie można także przejść obojętnie obok architektury obiektów. Mieszkalnictwo Nightingale charakteryzuje przede wszystkim prostota, minimalizm i czystość formy. Dominują kolory ziemi oraz czerń, duża ilość surowych betonowych elementów, a także przeskalowane okna z antracytowymi szprosami (Ryc. 8,10.). Przestronne wnętrza to popis architektoniczny łączący najmodniejsze elementy dekoratorskie na tle drewnianych mebli i podłóg oraz betonowych ścian i sufitów. Dopełnienie całości stanowi bujna roślinność w wazonach i donicach, podkreślająca naturalny i nieinwazyjny charakter przestrzeni. Nie sposób również nie zauważyć instalacji sanitarnych oraz wentylacyjnych wijących się wzdłuż ścian i sufitów (Ryc. 7,8.). Ich obecność nie zakłóca formy wnętrza, a przeciwnie dodaje uroku i oryginalnego charakteru. Wszystkie elementy są zrównoważone i kompatybilne. Warto dodać, że dla każdej nowej koncepcji modelu Nightingale tworzona jest swego rodzaju księga standardów, zawierająca między innymi szerokie opisy inwestycji, rzuty mieszkań oraz materiały, którymi powinny zostać wykończone (Nightingale, What is...).

Pomysłodawcy projektu za cel główny postawili sobie zapewnienie wysokiej jakości wyjątkowych mieszkań za rozsądną cenę. Za dowód przemawiający za osiągnięciem celu można uznać rosnącą liczbę zainteresowanych lokalami Nightingale, a tym samym życiem ekologicznym, etycznym i ukierunkowanym na społeczność. 


\section{PODSUMOWANIE}

Powyższe opisy wskazują na to, że pradawna sztuka feng shui, poglądy „ojca modernizmu” oraz świeże podejście modelu Nightingale mają ze sobą wiele wspólnego. W każdej z trzech odsłon recepty na dobrą przestrzeń, kluczowym elementem jest dostęp do światła. Le Corbusier mówił wprost o budynkach skąpanych w słońcu, zgodnie z feng shui również niewskazany jest niedostateczny dostęp do światła, a duże okna preferowane w Nightingale wpuszczają pod dostatkiem promieni słonecznych do surowych wnętrz lokali. Istotny jest kształt okien, ich rozmiar, kolor ram, a także storna świata, na którą wychodzą. W projektach Le Corbusiera przeważają olbrzymie przeszklenia o charakterze wstęgowym, osadzone w stalowych bądź drewnianych ramach w ciemnych odcieniach. W Marsylskich mieszkaniach tworzyły one jedną ze ścian wnętrza, dostarczając tym samym światło do każdego z zakątków lokalu. Dodatkowo, ważna była ekspozycja budynku na wschód i zachód oraz fakt, że wszystkie mieszkania zostały zaprojektowane na przestrzał. Te czynniki zapewniły dostęp do światła praktycznie przez cały dzień niezależnie od pory roku (Ryc. 5.). Strategią autorów modelu Nightingale jest: Budować więcej za mniej. Dostarczać tekstur, przestrzeni, wysokości, światła i powietrza (Nightingale, House...). Można zauważyć, że dwa ostatnie słowa szczególnie przypominają poglądy „ojca modernizmu”. W przypadku australijskiego modelu, jedynie niewielkie lokale typu open space posiadają okna na jedną stronę świata, wszystkie większe mieszkania realizowane są - jak u Le Corbusiera - na przestrzał, co oczywiście sprzyja doświetleniu i daje możliwość swobodnego przewietrzania (Cohen J.L., 2008). Kolejną cechą wspólną jest fakt, że w budynkach Nightingale dominują duże, prostokątne okna osadzone w solidnych, ciemnych ramach (Ryc. 8,10.). Filozofia feng shui również podkreśla wysoką rolę światła. Jest ono uważane nawet za lekarstwo, jednak tylko wtedy, gdy jego natężenie i kolor są właściwe. Niedostatek światła, zbyt mocne żarówki, gra cieni, odblaski, mogą stać się przyczyną poważnych zakłóceń emocjonalnych (Spear W. 1996, s.145). Według pradawnej filozofii, okna także powinny być dosyć szerokie żeby umożliwić swobodny przepływ dobrej energii. Jednak preferowane są takie w kształcie łukowym lub okrągłym, co akurat wyróżnia je na tle pozostałych dwóch teorii. Dodatkowo, kolor framug powinien różnić się od koloru ścian i stanowić tym samym ramę dla widoku rozpościerającego się za oknem (Feng Shui Windows) (Ryc. 13.). W tym miejscu widoczna jest silna analogia do poglądu Le Corbusier, że każdy widok musi mieć swoją ramę (Flint A. 2014, s. 57), bo czym jest perfekcyjne w swej istocie wnętrze, jeśli za oknem roztacza się brzydota, nieład, brud i dezorganizacja? Widok uspakaja i nastraja, jest dopełnieniem idealnego wnętrza. Architekt aranżował wnętrza i dostosowywał nawet meble, tak aby było z nich widać jak najwięcej tego, co rozpościera się za oknem. Mowa tutaj szczególnie o łóżkach na podwyższeniu, które Jeanneret zastosował w swoim paryskim apartamencie, w Cabanon czy w domu swoich rodziców - Maison Blanche (Flint A. 2014). W tym miejscu warto podkreślić, że lokalizacje jego budynków także nie były przypadkowe. Zawsze dobierał pod zabudowę miejsca wyjątkowe, o niebanalnym i inspirującym otoczeniu. W przypadku feng shui dodatkowo duży nacisk kładziony jest na percepcję wnętrza mieszkania. Filozofia radzi, że zapewnienie sobie szerokiego pola widzenia wewnątrz domu wzmaga poczucie siły, bezpieczeństwa i spokoju (Spear W. 1996, s.97). Co więcej, aspekt widoku z perspektywy łóżka jest także obecny. Nastrój podczas zasypiania warunkuje to, co człowiek widzi leżąc $\mathrm{w}$ łóżku. Dlatego ważne jest aby przedmioty umieszczone w sypialni były estetyczne i harmonijne, pozwalające osiągnąć spokój i wyciszenie. (Spear W. 1996, s.101). Kolor to kolejnym istotny punkt, na którym warto się skupić porównując te trzy teorie. W feng shui dominują stonowane kolory i biel. Te bardziej intensywne stosowane są sporadycznie, $w$ formie oszczędnych akcentów (Spear W. 1996, s.179). Na barwę dodatków stosowanych w mieszkaniu wpływ ma strona świata, na którą zorientowane jest pomieszczenie, na przykład w salonie wychodzącym na południe warto umieścić elementy w ciepłych odcieniach - czerwone czy żółte. Le Corbusier w Jednostce Mieszkaniowej także używał mocnych barw w celu podkreślenia białych ścian, między innymi stosując półki wnękowe w kolorach żółtym, niebieskim czy czerwonym, co dodatkowo dodawało indywidualnego charaktery przestrzeni. Podobne motywy kolorystyczne zostały zastosowane dla elewacji Jednostki. Balkony zostały odpowiednio potraktowane barwami podstawowymi (Ryc. 1.). Model Nightingale również wprowadza mocne kolory z dużym umiarem, jednak każdorazowo na elementach, których nie da się przeoczyć, jak na przykład w postaci czerwonych rur prowadzonych po suficie (Ryc. 7,8.). Pomimo obecności barwnych elementów, w każdej z trzech filozofii dominują stonowane barwy ziemi i naturalne materiały, kolor jedynie je podkreśla, stanowi ich dopełnienie. 
Zagospodarowanie wnętrza to kolejny ważny punkt w każdej z trzech odsłon teorii na dobrą przestrzeń. Le Corbusier sam projektował meble, które wprowadzał do mieszkań Jednostki Mieszkaniowej. Mowa szczególnie o krzesłach i fotelach ratanowo-drewnianych i skórzanych. Meble te miały niebanalną, ale jednocześnie minimalistyczną i prostą formę (Ryc. 11,12.). Bardzo podobne elementy dostrzegalne są w proponowanych przez pomysłodawców Nightingale aranżacjach. Dominują krzesła z jasnego drewna z siedziskami ratanowymi i sofy pokryte skórą. Reszta mebli przybiera bardzo subtelną i niedominującą formę (Ryc. $7,8,14$.). Wnętrza zgodne $z$ feng shui dopełniają meble proste. Istotne jest ich ustawienie w sposób taki aby przepływ ruchu wokół nich był niezakłócony. Nie mogą stanowić przeszkody ani blokować ciągów komunikacyjnych. Punktem centralnym każdego salonu jest sofa i to jej położenie jest kluczowe dla odbioru całego wnętrza. Nie powinna być ona zbyt duża i ciężka, zawsze warto ją dodatkowo zrównoważyć elementem takim jak dwa krzesła/fotele ustawione naprzeciw. Dobrym rozwiązaniem jest także odsunięcie jej nieco od ściany, co doda przestrzeni lekkości (Beauchamp M. 2020) (Ryc. 13.). Kolejny elementy spójny dla wszystkich filozofii, to prostota, minimalizm oraz porządek, rozumiany w taki sposób, że każdy przedmiot ma swoje określone miejsce i nie powinno się go ruszać, bo mała reorganizacja wnętrzarska może w sposób negatywny wpłynąć na globalny odbiór przestrzeni. Le Corbusier nawet swojej żonie Yvonne nie zezwalał na modyfikacje w ich domach, co spotykało się $z$ jej wyraźną niechęcią (Flint A. 2014, s. 195). W każdym z jego wnętrz, przemyślanym w szczegółach, nie było miejsca na przypadkowe przedmioty czy zabiegi. Podobieństwa znajdziemy także w wyglądzie zewnętrznym budynków. Preferowane są lekkie, prostokątne i kwadratowe bryły, bez zbędnych udziwnień i natłoku kolorów. Różnice również występują, na co bez wątpienia miała wpływ epoka, w której dane poglądy się kształtowały. W kontekście starożytnych Chin ciężko mówić o problemie wzmożonego ruchu samochodowego i deficycie miejsc parkingowych, jednak dla lokalizowania domów względem dróg znajdziemy już dokładne wytyczne. Dla Le Corbusiera natomiast samochód był bardzo istotnym elementem wizji nowego stylu życia, nieodłącznie związanym z budynkami, które projektował. Miał być kompatybilny z miastem, o ile to oczywiście zostanie zaprojektowane w sposób umożliwiający komunikację tym środkiem transportu. Architekt stworzył nawet prototyp własnego modelu, będący dopełnieniem jego wizji, do produkcji jednak nigdy nie doszło. W przypadku Nightingale, mamy do czynienia z całkowitym odcięciem od „czterech kółek”, na rzecz między innymi rowerów i komunikacji miejskiej. Świadomi współcześnie żyjący projektanci, zdając sobie sprawę, jak wiele szkody, szczególnie w miastach wyrządzają samochody, nie przewidzieli w swoich projektach parkingów. Osiedla bez dostępu dla aut, mają stać się zbawieniem dla zdrowia fizycznego i psychicznego mieszkańców. Istnieje także szereg innych podobieństw, które cechują model Nightingale i projekty Le Corbusiera, są to jednak cechy, w przypadku których ciężko znaleźć wspólny mianownik z domostwami starożytnych Chińczyków. Te elementy to np. wszechobecny beton, Le Corbusier budował całe domy z gładkiego lanego betonu, w modelu Nightingale także występują - ściany, sufity, posadzki z tego materiału. Należy także wspomnieć o wymiarze społecznym - Jednostka Mieszkaniowa i jej siódme piętro pełne lokali usługowych oraz dach z przedszkolem i miejscem do rekreacji (Ryc. 16.), w przypadku australijskiego modelu - cykliczne spotkania sąsiedzkie, aktywne partery z lokalami gastronomicznymi (dostępnymi także dla ludzi z zewnątrz, w Jednostce Mieszkaniowej z usług mogli korzystać tylko mieszkańcy) czy ogród na dachu (Ryc. 15).

Filozofia feng shui jest czymś ponadczasowym, Le Corbusier zrewolucjonizował podejście do architektury, natomiast model Nightingale wychodzi naprzeciw trendom świadomego społecznie budownictwa mieszkaniowego. Zdaniem autorki, każda z trzech teorii wnosi bardzo istotne wskazówki, jakie mieszkanie wybrać i jak je zorganizować żeby znacznie poprawić jakość swojego życia, osiągnąć szczęście, spokój i równowagę.

Tab. 1. Zestawienie wniosków. Źródło: opracowanie własne.

\begin{tabular}{|l|l|l|l|}
\hline Cecha/przedmiot & Filozofia feng shui & $\begin{array}{l}\text { Le Corbusier i Unité } \\
\text { d'Habitation }\end{array}$ & Model Nightingale \\
\hline $\begin{array}{l}\text { Dostęp do światła i po- } \\
\text { wietrza }\end{array}$ & $\begin{array}{l}\text { Wysoka rola światła. Jest } \\
\text { ono nawet uważane za }\end{array}$ & $\begin{array}{l}\text { Le Corbusier głosił, że klu- } \\
\text { czowy jest dostęp do świa- } \\
\text { tła, świeżego powietrza, }\end{array}$ & $\begin{array}{l}\text { Strategią autorów modelu } \\
\text { Nightingale jest: Budować } \\
\text { więcej za mniej. Dostarczać }\end{array}$ \\
\hline
\end{tabular}




\begin{tabular}{|c|c|c|c|}
\hline & lekarstwo. & $\begin{array}{l}\text { przestrzeni i zieleni (Le } \\
\text { Corbusier, 2017). }\end{array}$ & $\begin{array}{l}\text { tekstur, przestrzeni, wyso- } \\
\text { kości, światta i powietrza } \\
\text { (Nightingale, House...). }\end{array}$ \\
\hline $\begin{array}{l}\text { Wielość, rodzaj, kolor } \\
\text { okien. Rola widoku i } \\
\text { otoczenia. }\end{array}$ & $\begin{array}{l}\text { Okna powinny być dosyć } \\
\text { szerokie żeby umożliwić } \\
\text { swobodny przepływ dobrej } \\
\text { energii. Preferowane są } \\
\text { takie w kształcie łukowym } \\
\text { lub okrągłym. Kolor framug } \\
\text { powinien różnić się od kolo- } \\
\text { ru ścian i stanowić tym sa- } \\
\text { mym ramę dla widoku roz- } \\
\text { pościerającego się za ok- } \\
\text { nem. }\end{array}$ & $\begin{array}{l}\text { Le Corbusier preferował } \\
\text { olbrzymie przeszklenia o } \\
\text { charakterze wstęgowym, } \\
\text { osadzone w stalowych bądź } \\
\text { drewnianych ramach w } \\
\text { ciemnych odcieniach. Zaw- } \\
\text { sze dobierał pod zabudowę } \\
\text { miejsca wyjątkowe, o nie- } \\
\text { banalnym i inspirującym } \\
\text { otoczeniu. }\end{array}$ & $\begin{array}{l}\text { Dominują przeskalowane } \\
\text { prostokątne okna w antracy- } \\
\text { towych ramach, często na } \\
\text { całá ścianę. Ważne jest } \\
\text { harmonijne otoczenie. }\end{array}$ \\
\hline $\begin{array}{l}\text { Forma architektoniczna, } \\
\text { użyte materiały, dominu- } \\
\text { jące barwy }\end{array}$ & $\begin{array}{l}\text { Ceniona jest prostota, mi- } \\
\text { nimalizm, stonowane kolory } \\
\text { i biel. }\end{array}$ & $\begin{array}{l}\text { Dominuje beton, minima- } \\
\text { lizm, czystość formy. }\end{array}$ & $\begin{array}{l}\text { Preferowana jest prostota, } \\
\text { minimalizm i czystość for- } \\
\text { my, kolory ziemi oraz czerń, } \\
\text { duża ilość surowych beto- } \\
\text { nowych elementów. }\end{array}$ \\
\hline Zieleń & $\begin{array}{l}\text { Roślinność powinna być } \\
\text { zdrowa i bujna. }\end{array}$ & $\begin{array}{l}\text { Kluczowy jest dostęp do } \\
\text { światła, świeżego powie- } \\
\text { trza, przestrzeni i zieleni (Le } \\
\text { Corbusier, 2017). }\end{array}$ & $\begin{array}{l}\text { Wewnątrz lokali znajduje się } \\
\text { bujna roślinność w wazo- } \\
\text { nach i donicach. Elewacje } \\
\text { często pokrywa bluszcz. }\end{array}$ \\
\hline $\begin{array}{l}\text { Rola akcentów kolory- } \\
\text { stycznych }\end{array}$ & $\begin{array}{l}\text { Intensywne kolory stosowa- } \\
\text { ne są sporadycznie, w for- } \\
\text { mie oszczędnych akcentów. } \\
\text { Na barwę dodatków stoso- } \\
\text { wanych w mieszkaniu } \\
\text { wpływ ma strona świata, na } \\
\text { którą zorientowane jest } \\
\text { pomieszczenie, na przykład } \\
\text { w salonie wychodzącym na } \\
\text { południe warto umieścić } \\
\text { elementy w ciepłych odcie- } \\
\text { niach - czerwone czy żółte. }\end{array}$ & $\begin{array}{l}\text { Le Corbusier w Jednostce } \\
\text { Mieszkaniowej używał moc- } \\
\text { nych barw w celu podkre- } \\
\text { ślenia białych ścian, między } \\
\text { innymi stosując półki wnę- } \\
\text { kowe w kolorach żółtym, } \\
\text { niebieskim czy czerwonym. }\end{array}$ & $\begin{array}{l}\text { Model Nightingale wprowa- } \\
\text { dza mocne kolory z dużym } \\
\text { umiarem, jednak każdora- } \\
\text { zowo na elementach, któ- } \\
\text { rych nie da się przeoczyć, } \\
\text { jak na przykład w postaci } \\
\text { czerwonych rur prowadzo- } \\
\text { nych po suficie. }\end{array}$ \\
\hline Ustawienie i rodzaj mebli & $\begin{array}{l}\text { Wnętrza zgodne z feng shui } \\
\text { dopełniają meble proste. } \\
\text { Istotne jest ich ustawienie w } \\
\text { sposób taki aby przepływ } \\
\text { ruchu wokół nich był nieza- } \\
\text { kłócony. Nie mogą stanowić } \\
\text { przeszkody ani blokować } \\
\text { ciągów komunikacyjnych. } \\
\text { Punktem centralnym każ- } \\
\text { dego salonu jest sofa i to jej } \\
\text { położenie jest kluczowe dla } \\
\text { odbioru całego wnętrza. }\end{array}$ & $\begin{array}{l}\text { Le Corbusier wprowadzał } \\
\text { do mieszkań krzesła i fotele } \\
\text { ratanowo-drewniane oraz } \\
\text { skórzane swojego projektu. } \\
\text { Meble te miały niebanalną, } \\
\text { ale jednocześnie minimali- } \\
\text { styczną i prostą formę. }\end{array}$ & $\begin{array}{l}\text { Przeważają krzesła z ja- } \\
\text { snego drewna z siedziskami } \\
\text { ratanowymi i sofy pokryte } \\
\text { skórą. Reszta mebli przy- } \\
\text { biera bardzo subtelną i } \\
\text { niedominującą formę. }\end{array}$ \\
\hline Wymiar społeczny & $\begin{array}{l}\text { Feng shui nie odnosi się } \\
\text { wprost do relacji społecz- } \\
\text { nych, a bardziej do działań } \\
\text { mających przełożenie na } \\
\text { poprawę energii jednostki, a } \\
\text { w konsekwencji także na jej } \\
\text { relacje z innymi ludźmi. }\end{array}$ & $\begin{array}{l}\text { Jednostka Mieszkaniowa i } \\
\text { jej siódme piętro było pełne } \\
\text { lokali usługowych. Na da- } \\
\text { chu znajdowało się przed- } \\
\text { szkole z miejscem do re- } \\
\text { kreacji. }\end{array}$ & $\begin{array}{l}\text { Konsultacje społeczne od- } \\
\text { bywają się już na etapie } \\
\text { projektowania. W obrębie } \\
\text { budynków realizowane są } \\
\text { liczne przestrzenie wspólne, } \\
\text { cykliczne kolacje w są- } \\
\text { siedzkim gronie, a także } \\
\text { aktywne partery. }\end{array}$ \\
\hline Rola samochodu & $\begin{array}{l}\text { Trudno odnieść ten aspekt } \\
\text { do pradawnej filozofii. }\end{array}$ & $\begin{array}{l}\text { Bardzo ważna. Oparcie } \\
\text { Jednostki na betonowych } \\
\text { słupach pozwalało skrócić } \\
\text { drogę do parkingów. Le } \\
\text { Corbusier był zafascynowa- } \\
\text { ny samochodami, sam za- } \\
\text { projektował swój model, } \\
\text { który jednak nie został zrea- } \\
\text { lizowany. }\end{array}$ & $\begin{array}{l}\text { Praktycznie całkowite odej- } \\
\text { ście od „czterech kółek”, } \\
\text { propagowanie ruchu pie- } \\
\text { szego i rowerowego. Auto- } \\
\text { rzy nie przewidują parkin- } \\
\text { gów w obrębie osiedli. }\end{array}$ \\
\hline
\end{tabular}




\section{BIBLIOGRAPHY}

99\% Invisible, Unité d'Habitation: Le Corbusier's Proto-Brutalist Urban Sky Villages, 2018, źródło/source: https://99percentinvisible.org/article/unitedhabitation-le-corbusiers-proto-brutalist-urban-sky-villages/, dostęp/access: 2019-09-27.

Association des sites Le Corbusier, Unité d'habitation à Marseille, 2014, źródło/source: https://www.sites-lecorbusier.org/fr/unite-habitation, dostęp/access: 2019-09-27.

Beauchamp M., 10 Feng Shui Living Room Tips From An Expert to Bring the Good Vibes Home, 2020, źródło/source: https://www.mydomaine.com/feng-shui-living-room-tips, dostęp/access: 2020-05-08.

Brickworks. Building products, Is the Nightingale Housing model the architecture of the future?, 2019, źródło/source: https://brickworksbuildingproducts.com.au/article/nightingale-housing-model-architec turefuture/, dostęp/access: 2019-09-20.

Cohen J.L., Le Corbusier, Le Grand, Londyn, Phaidon Press Limited, 2008, ISBN 9780714849263.

Dezign Ark, Faberge Apartment, 2019, źródło/source: https://dezignark .com/blog/faberge-apartment/, dostęp/access: 2019-10-03.

Feng Shui Windows, źródło/source: https://www.yourchineseastrology.com/feng-shui/windows/, dostęp/access: 2020-04-20.

Flint A., Le Corbusier: Architekt jutra, Warszawa, Grupa Wydawnicza Foksal, 2014, ISBN 978-83-280-3343-6.

Gehl Blog, Hacking the australian housing model, 2018, źródło/source: https://gehlpeople.com /cities/hackingthe-australian-housing-model/, dostęp/access: 2019-10-03.

Gęsiarz M., Feng shui: Sekret szczęścia, miłości i bogactwa, Białystok, Studio Astropsycholgii, 2009, ISBN 978-83-7377-278-6.

Greek Architects, Le Corbusier by Willy Rizzo, 2012, źródło/source: https://www.greekarchitects.gr/site_parts/articles/print.php?article=6389\&language=encorbusier-s-citeradieuse.html, dostęp/access: 2019-09-15.

Le Corbusier, Karta ateńska, Warszawa, Fundacja Centrum Architektury, 2017, ISBN 9788394375065.

Le Corbusier, W stronę architektury, Warszawa, Fundacja Centrum Architektury, 2012, ISBN 978-83-9345748-9.

Nightingale, House Purchaser Package, źródło/source: https://nightingalehousing.org/s/NGSkye House_PurchaserPackage-3.pdf, dostęp/access: 2020-03-11.

Nightingale, Nightingale 1, źródło/source: https://nightingalehousing.org/nightingale-1, dostęp /access: 2019 10-05.

Nightingale, Nightingale 2, źródło/source: https://nightingalehousing.org/nightingale-2, dostęp /access: 201910-05.

Nightingale, What is the Nightingale Model?, źródło/source: https://nightingalehousing.org/nightigal e-1, dostęp/access: 2019-10-03.

Rybczyński W., Dom. Krótka historia idei, Gdańsk, Wydawnictwo Marabut, 1996, ISBN 83-86857-02-1.

Samuel F., Le Corbusier in Detail, Londyn, Routledge, 2007, ISBN 9781136388903.

Spear W., Feng shui: Tajniki harmonijnej aranżacji przestrzeni, Łódź, Wydawnictwo Ravi, 1996, ISBN 8385997-50-3.

Webster R., Feng shui: Jak zaplanować życie pełne sukcesów, Wrocław, Wydawnictwo Astrum, 1998, ISBN 83-87197-39-4.

\section{AUTHOR'S NOTE}

PhD student at the Institute of Architecture and Urban Planning of the Technical University of Łódź. Her scientific interests include spatial planning, urban housing, protection of cultural heritage of urban and rural centres.

\section{O AUTORZE}

Doktorantka Instytutu Architektury i Urbanistyki Politechniki Łódzkiej. Zainteresowania naukowe to planowanie przestrzenne, problematyka mieszkalnictwa miejskiego, ochrona dziedzictwa kulturowego ośrodków miejskich i wiejskich.

Contact | Kontakt: motylska.monika@gmail.com 